\title{
DOES FAMILIARITY BREED CONTEMPT AMONG JUDGES DECIDING PATENT CASES ${ }^{\dagger}$
}

\author{
Mark A. Lemley, ${ }^{*} \mathrm{Su} \mathrm{Li}{ }^{* *} \&$ Jennifer M. Urban***
}

We offer the first comprehensive look at how a district judge's experience affects decisionmaking in patent cases. We find that there is a strong, statistically significant relationship between a judge's experience and case outcome: more experienced judges are less likely to rule for the patentee. Notably, the relationship exists only for rulings finding noninfringement; judicial experience has no relationship to the likelihood a judge will find a patent invalid. The relationship appears to hold across judges rather than to be driven by the rulings of particular judges. Beyond individual judges, some technologies (such as biotechnology and mechanics) are associated with more patentee wins, while patentees are less likely to win computer hardware and software cases. Some district courts, such as the District of Delaware and the District of New Jersey, are more likely to find patents infringed. By contrast, perhaps surprisingly, we find no significant relationship between litigation in the Eastern District of Texas and a judge's ruling for or against the patentee. Finally, we find that suing on multiple patents is associated with an increased likelihood that at least one patent will be found to be infringed.

Our results challenge what has been an implicit assumption in the literature and discussion: that particular districts are biased in a particular direction, driving forum shopping. And they test for the first time the implicit assumption, made

$\dagger$ (C) 2014 Mark A. Lemley, Su Li, and Jennifer M. Urban.

* William H. Neukom Professor, Stanford Law School; Partner, Durie Tangri LLP.

** Ph.D. Statistician of Empirical Legal Studies, Center for the Study of Law \& Society, Berkeley Law School.

*** Assistant Clinical Professor of Law and Director, Samuelson Law, Technology \& Public Policy Clinic, Berkeley Law School.

We are grateful to Berkeley and Stanford law students Lucia Ballard, Erik Bauman, Christina Charemi, Chan Hee Chu, Jamie Kendall, Tiffany Lee, Amanda Rubin, Rob Swanson, and Randy Wu for data coding and research assistance, and to David Abrams, Judge Avern Cohn, Peter DiCola, Rochelle Dreyfuss, Michael Frakes, Rose Hagan, Amy Kapczynski, Greg Mandel, Peter Menell, Shawn Miller, Lisa Larrimore Ouellette, Lee Petherbridge, Michael Risch, David Schwartz, Chris Seaman, Melissa Wasserman, and participants at the IP Scholars Conference and the Empirical Patent Law Conference for comments on an earlier draft. 
in the literature, in calls for specialized patent trial courts, and in the Patent Pilot Program, that experience with patent cases at the trial level will lead to different-usually assumed to be "better"-outcomes from what we see from generalist courts. Our results suggest that there is a difference, but that "better" may be in the eye of the beholder. They suggest some sort of learning effect among district court judges across the country and indicate that patentees benefit from litigating before inexperienced judges, at least on issues of infringement. Depending on the reason for this effect, adoption of a specialized patent trial court might help accused infringers but not patentees, raising broader questions about patent reform and how to measure the value of an expert court.

INTRODUCTION.

I. SPECIALIZED PATENT COURTS AND FORUM SHOPPING …............................1125

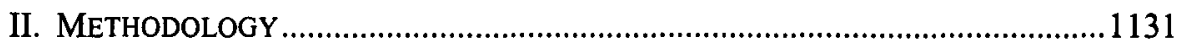

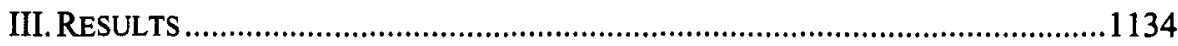

A. Descriptive Statistics …………………………………………............1134

1. Case outcomes..........................................................................1134

2. Judges and districts..................................................................1135

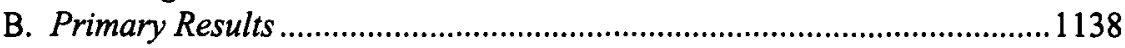

1. More experienced judges are more likely to vote against patentees ...............................................................................1138

2. District effects ...............................................................................1139

3. Infringement, not validity, explains the difference .............................1140

4. Technology-specific effects ...............................................................1144

5. The effect is driven by experience, not individual judges...................1148

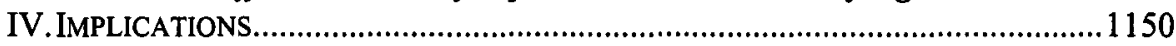

A. Familiarity Breeds Contempt-Sometimes..............................................1150

B. The Promise and Peril of Judicial Specialization ...................................1152

C. Future Work …….........................................................................1154

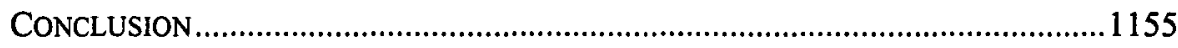

APPENDIX A .

\section{INTRODUCTION}

Judges notoriously dislike patent cases, which they view as arcane, complex, and surprisingly hard fought. Proponents of specialized trial courts for patent cases argue that patent litigation is inherently complex and involves technical factual background that is especially difficult and specialized. ${ }^{1}$ They

1. See, e.g., Court of Appeals for the Federal Circuit-1981: Hearings on H.R. 2405 Before the Subcomm. on Courts, Civil Liberties, \& the Admin. of Justice of the H. Comm. on the Judiciary, 97th Cong. 42-43 (1981) (statement of Howard T. Markey, C.J., Court of Customs and Patent Appeals) ("[I]f I am doing brain surgery every day, day in and day out, chances are very good that I will do your brain surgery much quicker, or a number of them, than someone who does brain surgery once every couple of years."); Rochelle Cooper Dreyfuss, Specialized Adjudication, 1990 BYU L. REV. 377, 378-79; Donna M. Gitter, Should the United States Designate Specialist Patent Trial Judges? An Empirical Analysis of 
would like to limit patent cases to judges with technical expertise, or at least to judges who have demonstrated a willingness to engage with patent law. ${ }^{2}$ The creation of the Federal Circuit was in part a response to such calls for specialization, though it was also designed to make the substantive law more patent friendly. ${ }^{3}$

Proponents of judicial specialization attribute the Federal Circuit's lamented reversal rate to judicial inexperience at the trial level, though much ink has been spilled on other reasons why the reversal rate might be high. ${ }^{4}$ Among other benefits, proponents of specialization expect it to produce both coherence in decisionmaking and a higher proportion of high-quality or "correct" decisions. 5 An experienced trial court, it is argued, could dispose of cases more accurately, more efficiently, and without forum shopping. Congress has responded by creating the Patent Pilot Program (PPP), ${ }^{6}$ intended to channel many patent cases in fourteen test districts to judges who opt to hear them. The PPP is not itself a specialized court, but it encourages specialization within a district, concentrating experience with patent cases in the hands of a few judges.

Others oppose specialized trial courts. Generalist courts, they argue, may be better able to connect specialty law with other doctrines and with broader societal interests. ${ }^{7}$ And specialized courts may be susceptible to forum shop-

H.R. 628 in Light of the English Experience and the Work of Professor Moore, 10 CoLUM. SCI. \& TECH. L. REV. 169, 175-77 (2009).

2. For an effort to study whether technical background makes a difference in decisions by Federal Circuit judges, see Dunstan H. Barnes, Technically Speaking, Does It Matter? An Empirical Study Linking the Federal Circuit Judges' Technical Backgrounds to How They Analyze the Section 112 Enablement and Written Description Requirements, 88 CHI.KENT L. REV. 971 (2013) (finding that judges with technical knowledge were more likely to reverse district courts). We originally planned to include a measure of technical specialization for district judges, but abandoned the effort because so few district judges had technical backgrounds.

3. See Rochelle Cooper Dreyfuss, The Federal Circuit: A Case Study in Specialized Courts, 64 N.Y.U. L. REV. 1, 17-19 (1989).

4. See, e.g., J. Jonas Anderson \& Peter S. Menell, Informal Deference: An Historical, Empirical, and Normative Analysis of Patent Claim Construction, 108 Nw. U. L. REV. 1, 5 (2014); Kimberly A. Moore, Are District Court Judges Equipped to Resolve Patent Cases?, 15 HARV. J.L. \& TECH. 1, 3-4 (2001); David L. Schwartz, Courting Specialization: An Empirical Study of Claim Construction Comparing Patent Litigation Before Federal District Courts and the International Trade Commission, 50 WM. \& MARY L. REV. 1699, 1704 (2009).

5. See Dreyfuss, supra note 1, at 378-79; Gitter, supra note 1, at 193, 195-99; Richard L. Revesz, Specialized Courts and the Administrative Lawmaking System, 138 U. PA. L. REV. 1111, 1116-18 (1990).

6. 28 U.S.C. $\$ 137$ note (2012) (Pilot Program in Certain District Courts).

7. See Simon Rifkind, $A$ Special Court for Patent Litigation? The Danger of a Specialized Judiciary, 37 A.B.A. J. 425, 425-26 (1951); Sarang Vijay Damle, Note, Specialize the Judge, Not the Court: A Lesson from the German Constitutional Court, 91 VA. L. REv. 1267,1269 (2005). 
ping, bias, and even capture, both because their importance depends on the continuing robustness of patent protection and because specialized judges are likely to spend time with lawyers who share that specialization. ${ }^{8}$ This concern is frequently voiced about the Federal Circuit and the de facto specialized docket in the Eastern District of Texas. ${ }^{9}$

So far, this literature has been based on speculation. It has been unable to tell us the answer to the question parties most care about when they take a case to a trial court: does judicial experience with patent cases affect how the judge rules in the case? The rich literature on Federal Circuit reversal rates cannot tell us. Reversal rates for experienced patent judges are not reliably different from those with less experience; ${ }^{10}$ in any case, reversal rates may be driven by any number of factors that are hard to separate from district judge experience. The answer may affect both statutory proposals for district court specialization and the focus of the courts and Congress on forum shopping.

In this Article, we offer the first comprehensive look at how a district judge's experience with patent cases affects that judge's decisionmaking. We look both at district outcomes and at outcomes by judge. Using both logistic regression and fixed effect analyses, we then relate outcomes to each judge's experience level, measured by the number of patent cases that judge decided over the observed time period.

We find a strong, statistically significant relationship between a judge's experience and case outcome: more experienced judges are less likely to rule for the patentee. Notably, this is true only of findings of infringement; judicial experience has no relationship to the likelihood a judge will find a patent invalid. The relationship between experience and outcome holds across all judges and is not driven by particular judges. We also find that patentees are more likely to win biotechnology and pharmaceutical patent cases and less likely to win computer cases.

Our findings suggest that some sort of learning effect is going on among district judges across the country and that patentees benefit from litigating be-

8. See Dreyfuss, supra note 1, at 379-81; Kimberly A. Moore, Forum Shopping in Patent Cases: Does Geographic Choice Affect Innovation?, 79 N.C. L. Rev. 889, 899 (2001); see also Holmes Grp., Inc. v. Vornado Air Circulation Sys., Inc., 535 U.S. 826, 839 (2002) (Stevens, J., concurring) ("[O]ccasional decisions [on issues of patent law] by courts with broader jurisdiction will provide an antidote to the risk that the specialized court may develop an institutional bias.").

9. See, e.g., Jay P. Kesan \& Gwendolyn G. Ball, Judicial Experience and the Efficiency and Accuracy of Patent Adjudication: An Empirical Analysis of the Case for a Specialized Patent Trial Court, 24 HARV. J.L. \& TECH. 393, 396 (2011); Arti K. Rai, Specialized Trial Courts: Concentrating Expertise on Fact, 17 BERKELEY TECH. L.J. 877, 896 (2002).

10. Kesan \& Ball, supra note 9, at 435; David L. Schwartz, Practice Makes Perfect? An Empirical Study of Claim Construction Reversal Rates in Patent Cases, 107 MiCH. L. REV. 223, 251-58 (2008). 
fore inexperienced judges. That learning effect is quite steep; judges who have heard even a few patent cases quickly become less likely to rule for the patentee. We cannot tell whether the effect results from substantive shifts in attitude-judges growing frustrated with repeated suits by patent trolls or overclaiming by patentees, for example-or represent a general increase in confidence in claim construction or assertiveness on the bench that comes with greater experience. It could even result from greater familiarity with the procedure in patent cases.

Depending on the reason for this effect, adoption of a specialized patent trial court, or other methods of increasing trial judges' experience with patent cases, might help accused infringers, not patentees. We are hesitant to conclude that the substantive effect of patent experience is either good or bad; that may depend both on one's views of whether we have too much patent protection and on what is causing the effect. But it is important to understand that judicial patent specialization is not substantively neutral; it is bound up with the outcome of the cases.

In Part I, we discuss the issues most relevant to debates over judicial specialization and forum shopping in patent law. In Part II, we explain our study methodology. Part III presents our results, focusing on the effect of judicial experience and district-specific results. Part IV offers some preliminary thoughts as to why more experienced judges are less likely to rule for patentees, discusses what our findings might mean for patent policy and patent reform, and suggests some paths for future work.

\section{SPECIALIZEd PATENT COURTS AND FORUM SHOPPING}

Whether specialized courts are a good idea is a longstanding question, considered at length in the literature. The general expected benefits include greater efficiency in case management and disposition, ${ }^{1 p}$ outcomes of higher "quality" or correctness in complex areas of fact or law, and more stable outcomes in similar cases, leading to coherent case law over time. ${ }^{12}$ Proponents argue that the creation of specialized courts would be beneficial for complex areas of law, especially those that are factually complex, ${ }^{13}$ because it would both improve

11. Dreyfuss, supra note 1, at 378; see also Revesz, supra note 5, at 1120.

12. Jay Kesan and Gwendolyn Ball ably chart the main arguments for and against specialized courts both generally and in the patent context; we will thus not review them in detail here. See Kesan \& Ball, supra note 9, at 400-17. They find that rationales on both sides sort into four basic categories: the formation of judicial human capital; the creation of uniform and predictable legal doctrine; effects on the political economy of the judicial system; and efficiency gains, including increased accuracy in decisionmaking. Id.

13. See, e.g., Dreyfuss, supra note 3, at 48 ("A trial judge who has never read a technical document before is less likely to interpret it correctly, no matter how many expert witnesses are called to testify, than an appellate judge who has extensive experience in dealing with such matters. Thus, it seems somewhat peculiar to allow a layman's decision to stand 
the accuracy of outcomes ${ }^{14}$ and streamline overloaded generalist dockets by giving time-consuming cases to judges with greater expertise. ${ }^{15}$ Some suggest that specialized courts may reduce forum shopping. ${ }^{16}$ Unsurprisingly, proposals for specialized patent trial courts are well represented in the academic literature, ${ }^{17}$ following the decision to concentrate expertise at the appellate level by creating the specialized Court of Appeals for the Federal Circuit, and have been regularly proposed in Congress. ${ }^{18}$ Other countries-notably South Korea, Japan, and the United Kingdom-presently use some manner of specialized courts for patent cases, ${ }^{19}$ and the European Union is currently seeking ratification of an agreement on a specialized Unified Patent Court. ${ }^{20}$

on a technical issue ... when the experienced judges of the [Federal Circuit], and the experts they employ, think that the finding is wrong, but not "clearly erroneous."'); LeRoy L. Kondo, Untangling the Tangled Web: Federal Court Reform Through Specialization for Internet Law and Other High Technology Cases, UCLA J.L. \& TECH., Spring 2002, at 1, 9.

14. Moore, supra note 8, at 932; see also Gitter, supra note 1, at 199; Damle, supra note 7 , at 1306.

15. Dreyfuss, supra note 1, at 377-78; see also Douglas H. Ginsburg \& Joshua D. Wright, Antitrust Courts: Specialists Versus Generalists, 36 FORDHAM INT'L L.J. 788, 793 (2013) (identifying efficiency, subject matter expertise, and uniformity as the three benefits offered for judicial specialization).

16. Charles W. Adams, The Court of Appeals for the Federal Circuit: More than a National Patent Court, 49 Mo. L. REV. 43, 45-46 (1984); Paul R. Gugliuzza, Rethinking Federal Circuit Jurisdiction, 100 GEO. L.J. 1437, 1448 (2012); Moore, supra note 8, at 931-32. In the case of patent courts, Kimberly Moore has argued that specialized trial (rather than appellate) courts would decrease forum shopping. Id.

17. See, e.g., Jeanne C. Fromer, Patentography, 85 N.Y.U. L. REv. 1444, 1477-93 (2010) (arguing for a change in venue rules that would promote natural specialization among district judges hearing patent cases, which would cluster in technology-intensive districts); John B. Pegram, Should There Be a U.S. Trial Court with a Specialization in Patent Litigation?, 82 J. PAT. \& TRADEMARK OFF. Soc'y 765, 767 (2000); Rai, supra note 9 at 877; Gregory J. Wallace, Note, Toward Certainty and Uniformity in Patent Infringement Cases After Festo and Markman: A Proposal for a Specialized Patent Trial Court with a Rule of Greater Deference, 77 S. CAL. L. REV. 1383, 1384 (2004).

18. H.R. 628, 111 th Cong. (2010); H.R. Res. 5418, 109th Cong. (2006); S. 3923, 109th Cong. (2006).

19. Kong-Woong Choe, The Role of the Korean Patent Court, 9 Fed. CIR. B.J. 473, 475-76 (2000); Adam Shartzer, Patent Litigation 101: Empirical Support for the Patent Pilot Program's Solution to Increase Judicial Experience in Patent Law, 18 FED. CIR. B.J. 191, 200-08 (2009); Christian Helmers \& Luke McDonagh, Patent Litigation in the UK 6-7 (London Sch. of Econ. \& Political Sci., LSE Law, Society and Economy Working Paper No. 12/2012, 2012), available at http://papers.ssm.com/sol3/papers.cfm? abstract_id=2154939. Notably, however, the United Kingdom has bucked the trend toward more judicial specialization, decreasing specialization on patents in recent reforms. The United Kingdom has two specialized patent trial courts, the Patents Court and the Patents County Court. Helmers \& McDonagh, supra, at 6.

20. EPO Emerges as Diplomatic Force over Unitary Patent and Language Barriers, NEwLegal REV. (July 9, 2013), http://newlegalreview.cpaglobal.com/epo-emergesdiplomatic-force-unitary-patent-language-barriers. 
Others raise concerns about specialized courts generally and patent courts specifically. The primary concern is capture of specialized courts by interested groups. ${ }^{21}$ Some scholars have more general concerns about the effect of isolating certain types of cases into specific courts. They worry about negative effects on both the specialty area of law and adjudication more generally. ${ }^{22}$ In patent law in particular, commentators have worried that a specialized court would ignore precedent from other courts in favor of its own views. ${ }^{23}$ This unease is longstanding; in 1951, Samuel Rifkind outlined his concerns that specialization would remove patent from the whole body of law of which it is a part. Rifkind worried this would lead to tunnel vision and the creation of a court with "a jargon of its own, thought-patterns that are unique, internal policies which it subserves and which are different from and sometimes at odds with the policies pursued by the general law." 24 Without the cross-pollination of legal theories from other areas of law, specialized courts could undermine, rather than enhance, the law's overall coherence. ${ }^{25}$

Moreover, the quality of specialized courts' overall decisions could suffer if their judges do not have sufficient exposure to related areas of law, such as

21. See Lawrence Baum, Specializing the Federal Courts: Neutral Reforms or Efforts to Shape Judicial Policy?, 74 JUDICATURE 217, 224 (1991) (arguing that specialized courts represent "efforts [by] interest groups to secure advantages for themselves," the main example of such an interest group being the federal government). Paul Gugliuzza similarly argues that the Federal Circuit's focus on government programs may tend to bias it in favor of the U.S. Patent and Trademark Office (PTO) and thus in favor of patent validity. Gugliuzza, supra note 16, at 1449, 1466; see also Jeffrey A. Lefstin, The Constitution of Patent Law: The Court of Customs and Patent Appeals and the Shape of the Federal Circuit's Jurisprudence, 43 LOY. L.A. L. REV. 843, 868-71 (2010) (arguing that the Federal Circuit was shaped by the fact that it was created out of the Court of Customs and Patent Appeals, which heard PTO appeals but not infringement cases).

22. See, e.g., Baum, supra note 21, at 217-18; Dreyfuss, supra note 1, at 413; Diane P. Wood, Generalist Judges in a Specialized World, 50 SMU L. REV. 1755, 1767 (1997).

23. Matthew F. Weil \& William C. Rooklidge, Stare Un-Decisis: The Sometimes Rough Treatment of Precedent in Federal Circuit Decision-Making, 80 J. PAT. \& TRADEMARK OfF. SOC'Y 791, 793 (1998). And indeed, over the past decade the Supreme Court has repeatedly criticized the Federal Circuit when it ignored Supreme Court precedent or departed from the general rule in other circuits. See, e.g., Bilski v. Kappos, $130 \mathrm{~S}$. Ct. 3218, 3222 (2010); Quanta Computer, Inc. v. LG Elecs., Inc., 553 U.S. 617, 621 (2008); KSR Int'l Co. v. Teleflex Inc., 550 U.S. 398, 407 (2007); MedImmune, Inc. v. Genentech, Inc., 549 U.S. 118, 137 (2007); eBay Inc. v. MercExchange, L.L.C., 547 U.S. 388, 390 (2006); see Daniel Kazhdan, Beyond Patents: The Supreme Court's Evolving Relationship with the Federal Circuit, 94 J. PAT. \& TRADEMARK OfF. SOC'Y 275, 279-82 (2012); see also John M. Golden, The Supreme Court as "Prime Percolator": A Prescription for Appellate Review of Questions in Patent Law, 56 UCLA L. REv. 657, 657 (2009) (arguing that periodic Supreme Court changes can prevent the "doctrinal ossification" that results from a specialized appellate court).

24. Rifkind, supra note 7, at 425.

25. See Dreyfuss, supra note 1, at 418-19. 
commercial and antitrust law, when deciding patent cases. ${ }^{26}$ Relatedly, commentators worry that specialist benches would attract judges who are less qualified overall. ${ }^{27}$ And some have suggested reducing specialization by granting jurisdiction in patent appeals to a few districts beyond the Federal Circuit to increase expertise in regulatory and administrative issues and to create intellectual competition and interplay between courts. ${ }^{28}$

At the same time, commentators sometimes limit such concerns to appellate courts on the theory that it is the appellate bench's job to consider legal development in light of other areas of law and that the trial bench can improve its factfinding work through specialized expertise. ${ }^{29}$ On this view, the Federal Circuit may have been the wrong place to introduce specialization; instead, what we need is a specialized trial bench. ${ }^{30}$ Indeed, some of the criticisms of the Federal Circuit have focused on its alleged "hyperactivity" in reviewing district court factual determinations. ${ }^{31}$ The worry that a specialized court will be too interested in the facts may be a problem for an appellate court that owes deference to trial court findings, but if anything it should be an affirmative benefit for a trial court that is supposed to make those findings.

There is already some degree of differential experience in patent cases. A handful of districts handle a relatively high proportion of the patent cases filed each year. ${ }^{32}$ And as our study shows, only a handful of judges in even fewer districts decided more than ten final patent rulings from 2002 through $2011 .^{33}$

Congress recently attempted to harness the perceived benefits of greater judicial expertise while avoiding concerns about specialized courts by establishing the PPP. ${ }^{34}$ Under the program, fourteen district courts give judges the option to reassign patent cases randomly assigned to them after filing; these cases are then randomly reassigned to a pool of judges in the district who have volunteered to hear patent cases. The idea is that judges who volunteer can develop greater expertise in patent cases. Supporters of the program expect that it

26. See id. at 425; Gugliuzza, supra note 16 , at 1466.

27. See, e.g., Dreyfuss, supra note 1, at 425-26; Gugliuzza, supra note 16, at 1468-70.

28. See Craig Allen Nard \& John F. Duffy, Rethinking Patent Law's Uniformity Principle, 101 Nw. U. L. REv. 1619, 1625 (2007); Diane P. Wood, Lecture, Is It Time to Abolish the Federal Circuit's Exclusive Jurisdiction in Patent Cases?, 13 CHI.-KENT J. INTELL. PROP. 1,9 (2013).

29. See Revesz, supra note 5, at 1167.

30. See Gugliuzza, supra note 16, at 1476; Moore, supra note 4, at 38; Rai, supra note 9 , at 878-79.

31. William C. Rooklidge \& Matthew F. Weil, Judicial Hyperactivity: The Federal Circuit's Discomfort with Its Appellate Role, 15 BERKELEY TECH. L.J. 725, 726-30, 739-40 (2000).

32. See PwC, 2013 PATENT Litigation Study 24 (2013), available at http://www.pwc.com/en_us/us/forensic-services/publications/assets/2013-patent-litigationstudy.pdf; Kesan \& Ball, supra note 9, at 396.

33. See infra Table 3 (listing those judges).

34. 28 U.S.C. $\$ 137$ note (2012) (Pilot Program in Certain District Courts). 
will increase efficiency by decreasing the time to decision and lowering litigation costs, while preserving the generalist nature of the district courts and preserving random assignment to forestall forum shopping. ${ }^{35}$

Supporters also expect the PPP to improve outcomes- to improve the quality of trial court decisionmaking. The definition of "quality" as it pertains to outcomes may be contested. For the most part, however, supporters expect to measure outcome quality by reversal rate, and hope that slowly concentrating experience will result in decisions that are "adjudicate[d] . . properly [rather than] ... . decided, unfortunately, incorrectly the first time and only decided correctly after they have come back from the Fed circuit." ${ }^{36}$

The bill establishing the PPP was consistently popular with industry groups-including hardware, software, pharmaceutical, and biotechnology companies-and was supported by the patent bar, indicating industry and bar support for at least the kind of "soft" specialization it creates. ${ }^{37}$ It unanimously passed the House several times with broad bipartisan support, eventually surmounting congressional concerns that mirrored the longstanding concerns about specialized courts described above. These concerns, which had caused the House Judiciary Subcommittee on Courts, Intellectual Property, and the Internet to reject earlier proposals for an actual specialized court, ${ }^{38}$ included fear that reforms would promote forum shopping, undermine the generalist nature of the federal district courts, and limit the "legal percolation" among district courts ${ }^{39}$ presumably by limiting the courts in which litigants want to file and thus limiting variety in decisions.

It is too soon to tell whether the PPP is working or failing on any of these measures, as it took effect only late in 2011 . However, some interesting preliminary data are available. In the first year of the program, in the Northern District of California and the Southern District of New York, nonvolunteer judges were keeping patent cases. As of January 2013, out of 143 cases filed in the Southern District of New York since the PPP's inception, only fourteen (10\%) had been declined by the initially assigned judge and sent to the volunteer pool. ${ }^{40}$ Still

35. For discussion of those benefits, see Nancy Olson, Comment, Does Practice Make Perfect? An Examination of Congress's Proposed District Court Patent Pilot Program, 55 UCLA L. REv. 745, 751, 762-71 (2008). But cf. Randall R. Rader, Addressing the Elephant: The Potential Effects of the Patent Cases Pilot Program and Leahy-Smith America Invents Act, 62 AM. U. L. REV. 1105,1107 (2013) (noting that parties may engage in forum shopping to have their case heard by a PPP judge).

36. 155 CONG. REC. 7604 (2009) (statement of Rep. Darrell Issa).

37. See Marius Meland, Special IP Trial Courts a Bad Idea, Lawyers Say, LAw360 (Feb. 1, 2006, 12:00 AM), http://www.law360.com/articles/5183/special-ip-trial-courts-abad-idea-lawyers-say (subscription required) (noting support for the PPP as an alternative to specialized trial courts).

38. 152 CoNG. REC. 20,596 (2006) (statement of Rep. Adam Schiff).

39. 156 ConG. REC. H8538 (daily ed. Dec. 16, 2010) (statement of Rep. Adam Schiff).

40. Robert Gunther \& Omar Khan, Patent Pilot Program, One Year Later, N.Y. L.J., Jan. 7, 2013, at S6. 
nascent but more complete data arrived with the end of the PPP's second year. ${ }^{41}$ Across all districts in the PPP, $31 \%$ of cases were reassigned over the first two years. ${ }^{42}$ Reassignments were still strikingly low in the Northern District of California, where only two cases out of 335 were reassigned, as well as in the Southern District of New York and the Central District of California--all courts with active patent dockets. ${ }^{43}$ While some of this may be due to nonvolunteer judges accepting cases related to pending matters already on their dockets, it may turn out that judges in at least some districts are more interested in hearing patent cases than our received wisdom would predict. ${ }^{44}$ And of course, if it turns out that nonparticipating judges would often prefer to gain experience themselves rather than reassign the cases, any benefits of additional experience will need to be attained some other way. We take up the relevance of our results to the PPP in Part IV.

Some of the disputes over judicial specialization boil down to ideological commitments or viewpoint. One might believe in the value of generalist courts in society regardless of what the evidence shows about particular case outcomes, for example. But other questions-such as whether judicial experience can shorten patent cases and bring down costs-are empirical questions that can be tested. Among other efforts, Jay Kesan and Gwendolyn Ball recently contributed a thorough review of PACER dockets, finding that experience with patent cases does seem to bring down the duration of a case, though this finding is moderate and contains substantial nuance. ${ }^{45}$

As to whether specialist results are "better" or of higher "quality," ongoing attempts to answer this question focus on reversal rates, looking both at differences between rulings by patent-expert Federal Circuit judges and rulings by others on the court ${ }^{46}$ and at whether Federal Circuit reversal rates overall vary

41. Ron Vogel, The Patent Pilot Program: Reassignment Rates and the Effect of Local Patent Rules, N.Y. INTELL. Prop. L. Ass'N Bull., Oct.-Nov. 2013, at 13, 13-15, available at https://stage.nyipla.org/images/nyipla/Documents/Bulletin/2013/OctNov2013Vogel.pdf.

42. Id. at 15 .

43. Id. at 14 tbl.2.

44. But that attraction is not universal. When new judges are added to a district, existing judges can transfer cases to them, and in many districts, patent cases are a favorite to "dump" on the new judge. In the District of Utah, for example, the newest of the nine district judges, Robert Shelby, who was appointed in September 2012, had 31 of the 83 open patent cases on his docket as of July 2013. U.S. District Court for the District of Utah, LEX MACHINA, https://law.lexmachina.com/court/utd (last visited July 31, 2013) (subscription required). His colleagues had clearly reassigned a disproportionate number of patent cases to him.

45. Kesan \& Ball, supra note 9 , at 428.

46. See John R. Allison \& Mark A. Lemley, How Federal Circuit Judges Vote in Patent Validity Cases, 27 FLA. ST. U. L. REV. 745, 759 (2000); Christian A. Chu, Empirical Analysis of the Federal Circuit's Claim Construction Trends, 16 BERKELEY TeCH. L.J. 1075 (2001); Kimberly A. Moore, Markman Eight Years Later: Is Claim Construction More Predictable?, 9 LEWIS \& CLARK L. REv. 231, 234-46 (2005). Notably, these studies do not show 
for different district courts or judges. ${ }^{47}$ Kesan and Ball also sought to measure some form of "quality" or accuracy in decisions in light of district court experience with patent cases, again by measuring the likelihood of reversal on appeal. They found that judges with more patent case experience were moderately more likely than their less experienced colleagues to be upheld on appeal on infringement findings. ${ }^{48}$ They also found that judges with recent claim construction experience will be upheld on claim construction, though this finding does not hold true for cumulative experience with claim construction over time, and others have found to the contrary. ${ }^{49}$ Kesan and Ball used the proxy of differences in reversal rates in light of experience with patent cases, a reasonable approach given the limitations of the PACER dataset. ${ }^{50}$ However, reversal rates are inherently bound up with questions about the Federal Circuit's own approach to patent cases, limiting their ability to shed light on the district courts' decisionmaking.

Differences in district court behavior are important because both proponents and opponents of judicial specialization rely on an implicit assumption that specialized courts produce different outcomes. This has not been directly studied for district courts prior to appeal. In this Article, we test that assumption by studying trial court outcomes directly.

\section{Methodology}

Using the Lex Machina database, ${ }^{51}$ we collected data on every final district court decision on a substantive patent issue filed between 2000 and 2012; the dataset totals 2185 cases. We excluded decisions made in 2000 because only certain districts made their decisions available on PACER during that period, and including that year would have biased the experience characteristics for judges in some districts. ${ }^{52} \mathrm{We}$ also excluded decisions made on cases filed in 2011 and 2012 because very few cases filed in those years had proceeded to decision by the fall of 2012, when we collected our data, and those that were decided so quickly were likely to be outliers in various respects. Because we were concerned with the behavior of district court judges, we excluded jury

a difference in reversal rates between patent- or technical-expert Federal Circuit judges and others on the court.

47. See Schwartz, supra note 10, at 225-26. Again, David Schwartz does not find that specialization reduces the chance of reversal. Id. at 255-56.

48. Kesan \& Ball, supra note 9, at 438.

49. Compare id. at 442 , with Schwartz, supra note 10 , at $258-59$ (finding no relationship between experience with claim construction and likelihood of affirmance).

50. Kesan \& Ball, supra note 9, at 435-36.

51. Lex Machina is the most comprehensive database of patent lawsuits filed since 2000. Access is available with a user account at http://law.lexmachina.com.

52. We tried the same models with and without 2001 data, which may also be limited in completeness. Our results remained the same. 
verdicts, though we did include judgment as a matter of law (JMOL) rulings after jury trial. ${ }^{53}$ We excluded default judgments, which we believe to largely represent either a settlement or an automatic win rather than a considered decision on the merits. And we excluded decisions that were only interim wins, such as denials of summary judgment, keeping only final rulings on the merits of an infringement, validity, or enforceability issue. ${ }^{54}$ We were left with 1298 observations in the multivariate analysis. Our unit of analysis is a decision on a patent; each observation represents a final ruling on a single patent in a case. ${ }^{55}$ The 1298 observations were contained in 1171 separate cases; a number of cases included multiple patents.

For each ruling, we collected a variety of data, including the name of the judge, whether the judge was a magistrate or district judge at the time of the ruling, the district in which the case was filed, the year decisions were made, the patent number and area of technology (by international patent class), who won the case, whether the victory was on infringement, validity, or some other ground, and whether there were decisions on multiple asserted patents. We hand coded the outcomes and bases for the rulings for each patent. ${ }^{56}$

53. For a recent study of jury verdicts in patent cases, see Mark A. Lemley et al., Rush to Judgment? Trial Length and Outcomes in Patent Cases, 41 AIPLA Q.J. 169 (2013).

54. This decision has the advantage of allowing us to make apples-to-apples comparisons. But it is important to note that it affects both the number and the nature of the decisions in our study. Prior work has found that district judges are more likely to hold patents invalid on summary judgment than to hold them valid; patentees are generally angling for a jury trial and may be less likely to move for summary judgment that their patent is valid. See John R. Allison, Mark A. Lemley \& David L. Schwartz, Understanding the Realities of Modern Patent Litigation, 92 TEX. L. ReV. (forthcoming 2014) (finding 430 decided motions for summary judgment of invalidity in cases filed in 2008 and 2009 , compared to only 125 decided motions for summary judgment of validity). Further, as one of us has observed elsewhere, because patentees generally must win on every issue, a final win for an accused infringer on a single issue usually disposes of the whole case, while a final win for the patentee on a single issue often will not mean that the patentee has won the whole case. See Mark A. Lemley, The Fractioning of Patent Law, in INTELLECTUAL PROPERTY AND THE COMMON LAW 504, 507 (Shyamkrishna Balganesh ed., 2013). As a result, one should not read our descriptive statistics as indicating the actual total patentee win rate; they do not.

Allison, Lemley, and Schwartz are currently at work on a paper collecting data on all merits rulings-including denials of summary judgment, not just final rulings on an issuefor certain years. Allison, Lemley \& Schwartz, supra. As a robustness check, we intend in future research to include data from that study to determine if including denials of summary judgment affects our results.

55. In a very small number of cases, different claims of the same patent were treated differently. When that happened, we coded each group of claims separately.

56. Coding was done by a group of four Stanford law students working under Lemley's supervision and two Berkeley law students working under Urban's supervision. They each coded test sets, which we compared for errors and coding refinement. The remainder of the cases were coded with spot-check review that showed a high degree of reliability. 
For each judge, we determined when she took the bench. For each decision rendered by that judge in our dataset, we determined how many years she had been on the bench at the time of decision and how many prior patent decisions she had issued up until that point since the year 2000. That allowed us to calculate an "experience" variable using the total number of patent cases a judge had handled at the time of decision (between 2000 and 2010) divided by the number of years the judge had been on the bench by that time, giving us the average number of patent decisions per year for each judge at the time each ruling was made. We made the experience variable our primary dependent variable for two reasons. First, if there is a learning effect, it seems likely that the intensity of exposure to patent cases, not merely the fact that a judge had a few scattered cases over forty years of service, would be responsible for that learning. Second, because the available electronic records are reliable only back to 2001, we have no comprehensive data on decisions before that time. A measure of "total patent cases decided" would therefore be accurate for judges appointed in 2000 or later but underinclusive for judges appointed before 2000 . Nonetheless, we also report data on the total number of patent cases each judge had previously decided since 2000 at the time of each ruling and the total number of years the judge had served on the bench at the time of that ruling.

Our experience variable was not a static number but rather recalculated anew for each case, capturing growing experience over time. This was our main independent variable. We considered the following dependent variables: whether the patentee won a ruling, whether noninfringement was found, and whether a patent was found valid.

We used a variety of controls. Out of the seventy-four districts represented in the data, we created dummy variables for each of the "big" patent districts, chosen according to the volume of cases filed during the period of the study. ${ }^{57}$ These districts were coded as dummy variables to be compared to the remaining "small districts." We also created a dummy variable to indicate those "big" patent law districts as a set. We then used the "big district" dummy variables as controls to tell us whether each decision was rendered in one of the top patent districts. We also controlled for whether there were multiple patents at issue, the area of technology, and the year a case was decided (to account for substantive changes in the law over time). We clustered robust standard errors on cases to avoid skewing results in multipatent cases. And we included individualjudge fixed effects, though for reasons of sample size we were able to do that only for judges with fifteen or more decisions in the database.

We ran logistic regressions with all the control variables mentioned above. We also ran fixed effect logistic regressions with both years of experience (judge's time on bench) and total number of patent cases, but we discarded

57. We defined a big district as one with more than fifty final decisions in our dataset. There were nine such districts. See infra Table 2. 
those models because they had substantial collinearity with the patent-casesper-year measure of experience. ${ }^{58}$

\section{RESULTS}

In Subpart A, we report a variety of descriptive statistics about the districts and judges deciding the cases we studied. Relatively few judges have decided a large number of patent cases, and they are concentrated in just a few districts. In Subpart B, we report our primary regression results.

\section{A. Descriptive Statistics}

We collected a variety of descriptive statistics in the course of our research. We report some of these below to aid in ongoing understanding of the patent litigation system. ${ }^{59}$ Among the more notable descriptive results are the relatively small number of judges (and districts) with substantial experience with patent cases and the low number of prior patent decisions the average judge has made when rendering a patent decision. Patent litigation, it seems, is already specialized in the district courts to some extent.

\section{Case outcomes}

Patentees won just over $20 \%$ of the substantive rulings in our dataset, a number that is consistent with-albeit slightly lower than-prior findings. ${ }^{60}$ The disparity results from the fact that our study focuses only on judge decisions, excluding jury trials, and juries are more likely to favor patentees. ${ }^{61}$

58. That is, judges who have been on the bench longer are naturally likely to have had more total patent cases, so in a regression analysis that includes both variables, the two variables are likely to interfere with each other, making it difficult to find either one statistically significant.

59. Note that some of the data reflected in these descriptive tables do not include 2001. Only about half of the federal courts reported via PACER in 2001; as such, for absolute counts-for example, showing the number of cases a given judge heard during the date range-including 2001 confuses the results. It does not, however, affect the results of our regressions, so we didn't remove it from those results.

60. See, e.g., John R. Allison \& Mark A. Lemley, Empirical Evidence on the Validity of Litigated Patents, 26 AIPLA Q.J. 185, 212 (1998) (finding that plaintiffs finally won 28\% of cases resolved on pretrial motions from the period 1989-1996); Allison, Lemley \& Schwartz, supra note 54 (finding the win rate unchanged nearly twenty years later); Paul M. Janicke \& LiLan Ren, Who Wins Patent Infringement Cases?, 34 AIPLA Q.J. 1, 3 (2006) (finding a plaintiff win rate of $25 \%$ ).

61. See Allison \& Lemley, supra note 60, at 211 (finding that patentees won $67 \%$ of jury trials but only $28 \%$ of pretrial resolutions); Lemley et al., supra note 53, at 175-76; Kimberly A. Moore, Judges, Juries, and Patent Cases-An Empirical Peek Inside the Black Box, 99 MiCH. L. REV. 365, 369 (2000). 
shows the distribution of patents resolved in the top ten districts. Table 3 reports all the judges with ten or more final patent decisions in our dataset. ${ }^{63}$

\section{FIGURE 1}

Number of Patent Rulings by District

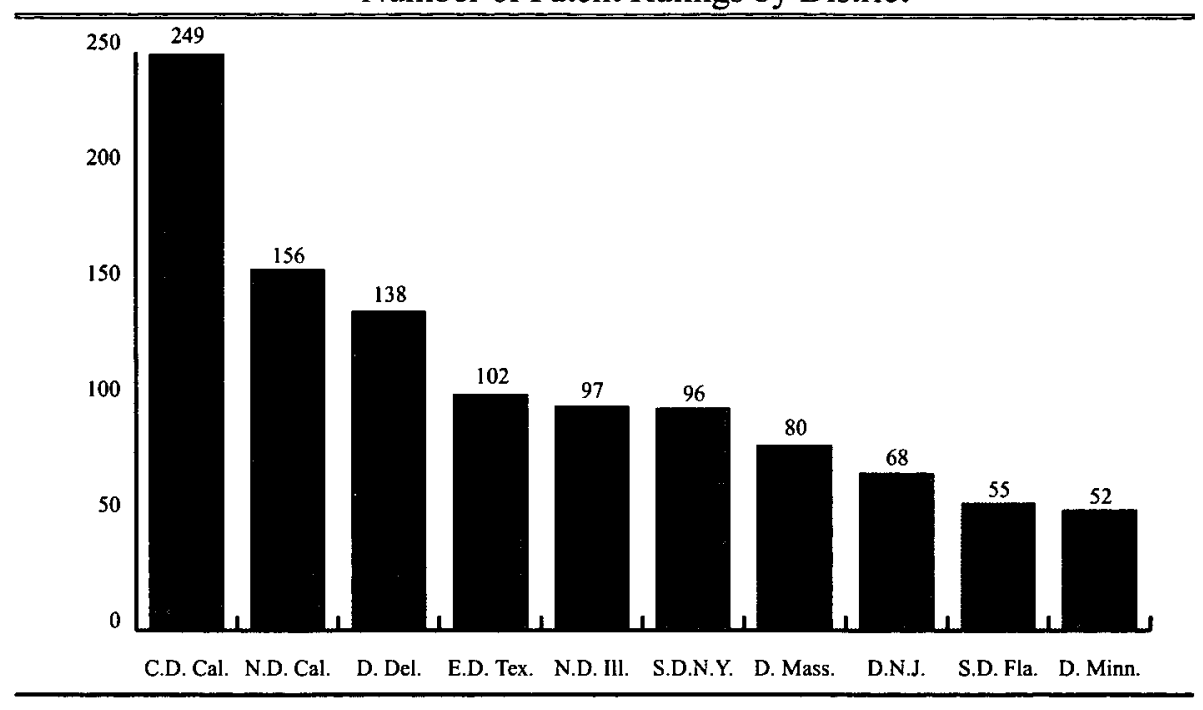

TABLE 2

Number and Percentage of Patent Rulings by District

\begin{tabular}{lcc}
\hline District & Number of Rulings & Percentage Decided \\
\hline C.D. Cal. & 249 & $12.5 \%$ \\
N.D. Cal. & 156 & $7.8 \%$ \\
D. Del. & 138 & $6.9 \%$ \\
E.D. Tex. & 102 & $5.1 \%$ \\
N.D. Ill. & 97 & $4.9 \%$ \\
S.D.N.Y. & 96 & $4.8 \%$ \\
D. Mass. & 80 & $4.0 \%$ \\
D.N.J. & 68 & $3.4 \%$ \\
S.D. Fla. & 55 & $2.8 \%$ \\
D. Minn. & 52 & $2.6 \%$ \\
\hline
\end{tabular}

63. Table 3 reports all decisions, including jury decisions and motions to dismiss that we later dropped from the substantive analysis. 
TABLE 3

Judges Who Finally Ruled on Ten or More

Substantive Patent Cases Between 2001 and 2010

\begin{tabular}{|lll|}
\hline \multicolumn{1}{|c}{ Judge } & \multicolumn{1}{c}{ District } & $\begin{array}{c}\text { Number of Patent } \\
\text { Cases Finally Resolved }\end{array}$ \\
\hline Sue Lewis Robinson & D. Del. & 50 \\
\hline T. John Ward & E.D. Tex. & 28 \\
\hline Leonard E. Davis & E.D. Tex. & 27 \\
Joseph James Farnan, Jr. & D. Del. & 25 \\
\hline Gregory Moneta Sleet & D. Del. & 24 \\
\hline Barbara B. Crabb & W.D. Wis. & 23 \\
\hline Ron Clark & E.D. Tex. & 20 \\
Kent A. Jordan & D. Del. & 19 \\
\hline James Selna & C.D. Cal. & 19 \\
\hline Susan Yvonne Illston & N.D. Cal. & 18 \\
\hline David Carter & C.D. Cal. & 15 \\
\hline Mariana Pfaelzer & C.D. Cal. & 15 \\
\hline Garrett Brown & D.N.J. & 14 \\
\hline Manuel Real & C.D. Cal. & 13 \\
\hline Gary Taylor & C.D. Cal & 13 \\
\hline James Ware & N.D. Cal. & 13 \\
\hline David J. Folsom & E.D. Tex. & 12 \\
\hline Rya Zobel & D. Mass. & 12 \\
\hline William Haskell Alsup & N.D. Cal. & 11 \\
\hline Avern Cohn & E.D. Mich. & 11 \\
\hline Marilyn Hall Patel & N.D. Cal. & 11 \\
\hline Mary Pat Thynge & D. Del. & 11 \\
\hline John C. Shabaz & W.D. Wis & 10 \\
\hline William Young & D. Mass. & 10 \\
\hline & & \\
\hline
\end{tabular}


B. Primary Results

1. More experienced judges are more likely to vote against patentees

The primary results of our logistic regression model are reported in Table 4. We find that judges with more experience deciding patent cases are less likely to find for the patentee.

TABLE 4

Logistic Regression: Patentee Wins Against Judge "Experience" Variable

\begin{tabular}{|c|c|c|c|c|c|c|}
\hline & $\begin{array}{l}\text { Odds } \\
\text { Ratio }\end{array}$ & $\begin{array}{l}\text { Robust } \\
\text { Std. Err. }\end{array}$ & Z-Score & P-Value & \multicolumn{2}{|c|}{$\begin{array}{l}\text { 95\% Confidence } \\
\text { Interval }\end{array}$} \\
\hline $\begin{array}{l}\text { Experience } \\
\text { Variable }\end{array}$ & 0.656 & 0.110 & -2.50 & $0.012^{*}$ & 0.472 & 0.912 \\
\hline $\begin{array}{l}\text { Multipatent } \\
\text { Case }\end{array}$ & 1.451 & 0.289 & 1.87 & 0.061 & 0.982 & 2.145 \\
\hline \multicolumn{7}{|l|}{ District } \\
\hline E.D. Tex. & 1.059 & 0.477 & 0.13 & 0.899 & 0.438 & 2.558 \\
\hline C.D. Cal. & 0.868 & 0.215 & -0.57 & 0.569 & 0.534 & 1.412 \\
\hline N.D. Cal. & 0.517 & 0.164 & -2.08 & $0.038^{*}$ & 0.278 & 0.963 \\
\hline D. Del. & 2.534 & 0.814 & 2.90 & $0.004^{*}$ & 1.351 & 4.755 \\
\hline N.D. Ill. & 0.886 & 0.314 & -0.34 & 0.733 & 0.443 & 1.774 \\
\hline S.D.N.Y. & 1.282 & 0.393 & 0.81 & 0.418 & 0.703 & 2.338 \\
\hline D.N.J. & 1.975 & 0.629 & 2.14 & $0.033^{*}$ & 1.058 & 3.687 \\
\hline D. Mass. & 1.475 & 0.478 & 1.20 & 0.230 & 0.781 & 2.784 \\
\hline S.D. Fla. & 0.684 & 0.375 & -0.69 & 0.488 & 0.234 & 2.001 \\
\hline D. Minn. & 0.846 & 0.422 & -0.33 & 0.738 & 0.319 & 2.247 \\
\hline \multicolumn{7}{|l|}{ Year } \\
\hline 2002 & 0.703 & 0.283 & -0.88 & 0.380 & 0.320 & 1.545 \\
\hline 2003 & 0.919 & 0.348 & -0.22 & 0.824 & 0.438 & 1.929 \\
\hline 2004 & 0.609 & 0.239 & -1.27 & 0.206 & 0.282 & 1.313 \\
\hline 2005 & 0.661 & 0.250 & -1.10 & 0.273 & 0.315 & 1.387 \\
\hline 2006 & 0.918 & 0.337 & -0.23 & 0.815 & 0.447 & 1.883 \\
\hline 2007 & 0.644 & 0.238 & -1.19 & 0.235 & 0.312 & 1.330 \\
\hline 2008 & 0.580 & 0.231 & -1.37 & 0.172 & 0.266 & 1.268 \\
\hline 2009 & 0.755 & 0.283 & -0.75 & 0.455 & 0.362 & 1.576 \\
\hline 2010 & 0.654 & 0.253 & -1.10 & 0.272 & 0.307 & 1.395 \\
\hline Constant & 0.381 & 0.122 & -3.02 & $0.003^{*}$ & 0.204 & 0.713 \\
\hline
\end{tabular}


* Significant at $95 \%$ level

Number of observations $=1271$

Wald Chi-squared $(21)=40.34$

Pearson's Chi-squared $=0.0068$

Pseudo R-squared $=0.0333$

Log pseudo likelihood $=-626.4253$

Standard error adjusted for 1184 clusters by case

The dependent variable in this regression is patentee win-that is, that the patent was both valid and infringed. We report the results in the form of an odds ratio. In this form, an odds ratio of below 1 (or a negative z-score) indicates that the independent variable makes a patentee win less likely, and a ratio above 1 (or a positive $\mathrm{z}$-score) indicates that a patentee win is more likely. The magnitude of the odds ratio indicates the strength of the effect, though there is not a simple relationship between how far that number is from 1 and the likelihood of a patentee win.

Notably, the more patent cases a judge has had per year at the time he decides a case, the less likely the judge is to rule for the patentee. That effect is highly statistically significant $(p=0.012)$. The effect is driven by the intensity of experience with patent cases, not simply time on the bench. In a separate regression, not reported here, total time on the bench was actually correlated with an increased likelihood of patentee win, while the total number of patent decisions pointed in the opposite direction. But as noted above, we do not think total patent decisions is a useful measure, since it is truncated in 2000 . Patent decisions per year is a more reliable measure of exposure to the patent system.

\section{District effects}

Our results may also have some implications for forum shopping. ${ }^{64}$ In the first model, we find that patentees are more likely to win cases in the District of Delaware and the District of New Jersey, while they are less likely to win cases in the Northern District of California. Interestingly, despite the patent-friendly reputation of the Eastern District of Texas, it is not significantly more likely to produce patentee wins. We note, however, that because our dataset includes only final decisions, these results do not account for the possibility that patentees may be more likely to get to trial in those districts ${ }^{65}$ or may be proportionally

64. On forum shopping in patent cases, see Chester S. Chuang, Offensive Venue: The Curious Use of Declaratory Judgment to Forum Shop in Patent Litigation, 80 GEO. WASH. L. REV. 1065, 1072 (2012); and Moore, supra note 8, at 891-92.

65. In fact, prior work has shown that patentees are more likely to get to trial in the District of Delaware and the Eastern District of Texas than elsewhere. See Mark A. Lemley, Where to File Your Patent Case, 38 AIPLA Q.J. 1, 12 tbl.4 (2010). 
more likely than in other districts to win at trial ${ }^{66}$ or to procure a favorable settlement from a dispute filed there. They also do not account for the fact that nonpracticing entities make up a higher proportion of plaintiffs in the Eastern District of Texas than in other districts ${ }^{67}$ or for potential selection effects that might send lower-quality patent cases to the Eastern District of Texas. ${ }^{68}$ As a result, we urge caution in concluding that one district is necessarily more patent friendly than another.

We also directly compared the large districts to one another by performing pairwise comparisons of each against one another and against the set of all smaller districts, using a t-test. The results of these tests confirm the statistical significance of our regression results and provide another way of ranking districts according to patentee win rate. These results track our regression results: the Districts of Delaware and New Jersey are more likely to find for patentees, including against other large districts; the Northern District of California is much less likely to find for patentees when compared to the other large districts; and the Eastern District of Texas shows no significant differences.

\section{Infringement, not validity, explains the difference}

When we break out the results by the basis for decision, it becomes evident that infringement, not validity, rulings are driving the judicial experience result. Table 5 shows the results for infringement-related motions, and Table 6 the results for validity-related motions.

66. Patentees are much more likely to win in front of a jury than they are in front of a judge. See PwC, supra note 32, at 5; Allison \& Lemley, supra note 60, at 211; Lemley et al., supra note 53, at 175. Moreover, they can expect far higher awards from juries. But this does not hold for repeat plaintiffs, who "overwhelmingly" lose both bench judgments and trial verdicts. John R. Allison et al., Patent Quality and Settlement Among Repeat Patent Litigants, 99 GEO. L.J. 677, 680 (2011). The latter result seems to be driven by the fact that nonpracticing entities and those wielding software patents enforced multiple times do poorly in court. Id. at 677.

67. Nonpracticing entities are generally less likely than practicing entities to win before both judges and juries, Allison et al., supra note 66 , at 692-94, though like all patentees, they do better before juries, PwC, supra note 32, at 12 .

68. George Priest and Ben Klein hypothesized decades ago that plaintiff win rates in litigation should approach $50 \%$ because of selection effects. George L. Priest \& Benjamin Klein, The Selection of Disputes for Litigation, 13 J. LeGal STUD. 1, 24 (1984). Whether or not this is true in other areas of the law, see Steven Shavell, Any Frequency of Plaintiff Victory at Trial Is Possible, 25 J. Legal StUd. 493, 494 (1996), every empirical study of patent law refutes it; each (including ours) shows systematic variation from a $50 \%$ win rate. See, e.g., supra Table 1. Whether that is a problem with the theory or represents something specific about patent law is beyond the scope of this Article. But while we do not think one can conclude that plaintiff win rates should approach $50 \%$, the basic insight of the PriestKlein hypothesis--that selection effects can significantly skew the set of cases litigated to judgment-is correct. 
TABLE 5

Logistic Regression: Accused Infringer Wins Against Infringement Motions

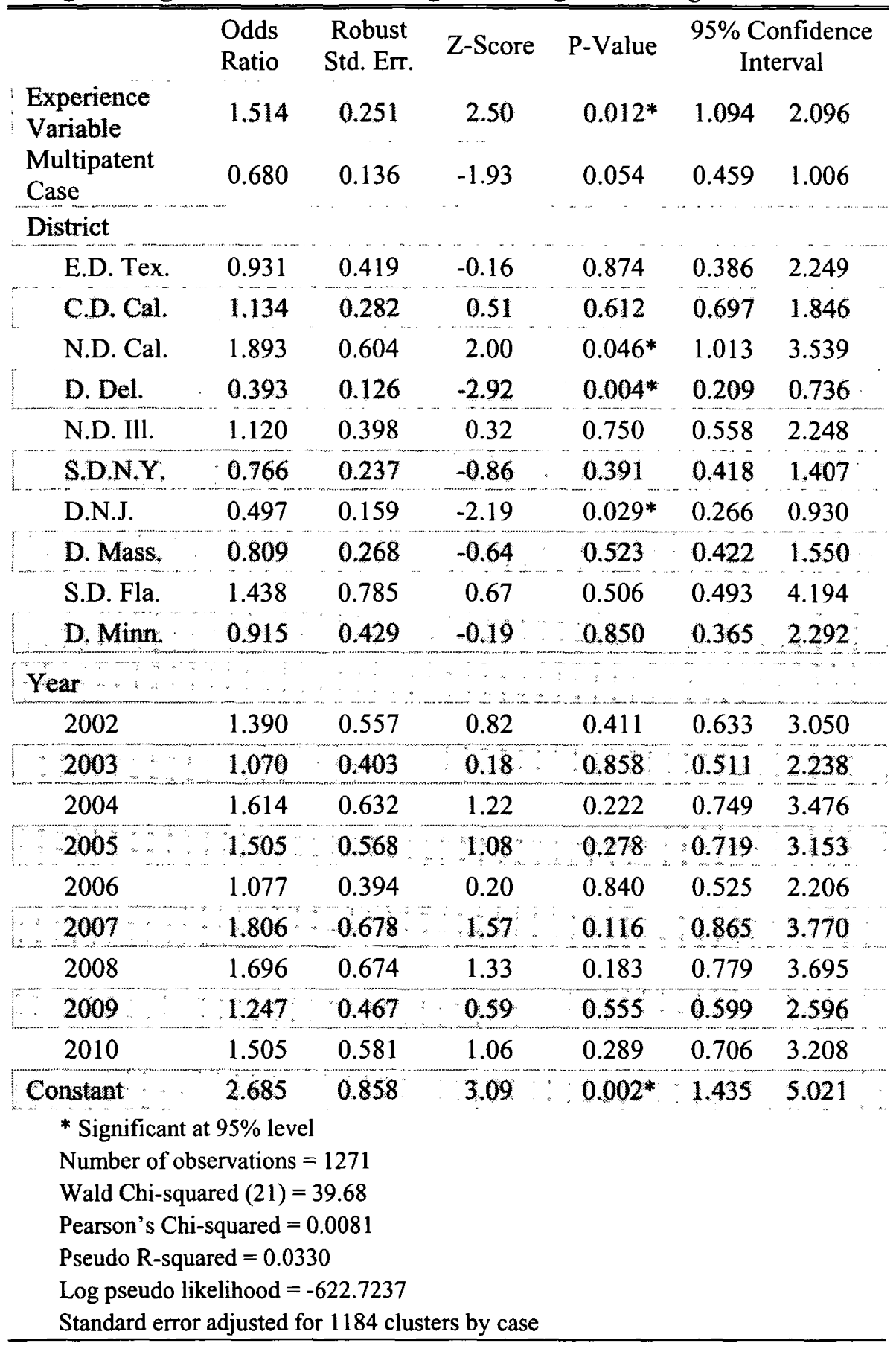


TABLE 6

Logistic Regression: Invalidity Against Invalidity Motions

\begin{tabular}{|c|c|c|c|c|c|c|}
\hline \multirow[b]{2}{*}{$\begin{array}{l}\text { Experience } \\
\text { Variable }\end{array}$} & \multirow{2}{*}{$\begin{array}{l}\text { Odds } \\
\text { Ratio } \\
1.056\end{array}$} & \multirow{2}{*}{$\begin{array}{c}\begin{array}{c}\text { Robust } \\
\text { Std. Err. }\end{array} \\
0.118\end{array}$} & \multirow{2}{*}{$\begin{array}{c}\text { Z-Score } \\
0.49\end{array}$} & \multirow{2}{*}{$\begin{array}{c}\text { P-Value } \\
0.623\end{array}$} & \multicolumn{2}{|c|}{$\begin{array}{l}95 \% \text { Confidence } \\
\text { Interval }\end{array}$} \\
\hline & & & & & 0.849 & 1.315 \\
\hline $\begin{array}{l}\text { Multipatent } \\
\text { Case }\end{array}$ & 1.183 & 0.216 & 0.92 & 0.356 & 0.828 & 1.692 \\
\hline \multicolumn{7}{|l|}{ District } \\
\hline E.D. Tex. & 1.723 & 0.627 & 1.50 & 0.135 & 0.844 & 3.515 \\
\hline C.D. Cal. & 1.033 & 0.219 & 0.15 & 0.878 & 0.682 & 1.565 \\
\hline N.D. Cal. & 1.739 & 0.393 & 2.45 & $0.014^{*}$ & 1.117 & 2.707 \\
\hline D. Del. & 1.209 & 0.369 & 0.62 & 0.535 & 0.665 & 2.198 \\
\hline N.D. Ill. & 1.484 & 0.437 & 1.34 & 0.180 & 0.833 & 2.642 \\
\hline S.D.N.Y. & 1.378 & 0.410 & 1.08 & 0.280 & 0.770 & 2.468 \\
\hline D.N.J. & 1.065 & 0.362 & 0.19 & 0.852 & 0.547 & 2.073 \\
\hline D. Mass & 0.503 & 0.203 & -1.70 & 0.088 & 0.228 & 1.108 \\
\hline S.D. Fla. & 1.129 & 0.481 & 0.28 & 0.776 & 0.490 & 2.601 \\
\hline D. Minn & 1.664 & 0.714 & 1.19 & 0.235 & 0.718 & 3.857 \\
\hline \multicolumn{7}{|l|}{ Year } \\
\hline 2002 & 1.202 & 0.487 & 0.45 & 0.649 & 0.543 & 2.661 \\
\hline 2003 & 0.541 & 0.224 & -1.48 & 0.138 & 0.240 & 1.220 \\
\hline 2004 & 1.433 & 0.535 & 0.96 & 0.335 & 0.690 & 2.979 \\
\hline 2005 & 1.065 & 0.395 & 0.17 & 0.865 & 0.515 & 2.203 \\
\hline 2006 & 1.316 & 0.490 & 0.74 & 0.460 & 0.635 & 2.729 \\
\hline 2007 & 1.262 & 0.458 & 0.64 & 0.520 & 0.620 & 2.569 \\
\hline 2008 & 2.262 & 0.828 & 2.23 & $0.026^{*}$ & 1.104 & 4.636 \\
\hline 2009 & 2.065 & 0.746 & 2.01 & $0.045^{*}$ & 1.017 & 4.193 \\
\hline 2010 & 1.435 & 0.537 & 0.96 & 0.335 & 0.689 & 2.990 \\
\hline Constant & 0.223 & 0.071 & -4.72 & $0.000^{*}$ & 0.120 & 0.416 \\
\hline \multicolumn{7}{|c|}{ * Significant at $95 \%$ level } \\
\hline \multicolumn{7}{|c|}{ Number of observations $=1271$} \\
\hline \multicolumn{7}{|c|}{ Wald Chi-squared $(21)=45.17$} \\
\hline \multicolumn{7}{|c|}{ Pearson's Chi-squared $=0.0016$} \\
\hline \multicolumn{7}{|c|}{ Pseudo R-squared $=0.0312$} \\
\hline \multicolumn{7}{|c|}{ Log pseudo likelihood $=-622.7237$} \\
\hline Standard erro & adjusted & 1104 & & & & \\
\hline
\end{tabular}


Note that because we are testing the likelihood of a finding of noninfringement (Table 5) or invalidity (Table 6), the significance of the odds ratios is reversed. That is, a positive z-score (or an odds ratio above 1 ) is associated with an increased likelihood of accused infringer win.

The results are depicted graphically in Figures 2 and 3. In those Figures, we have clustered groups of decisions by the average number of prior patent decisions per year the judge had rendered at the time that case was decided. As these Figures show, the results are driven by an increased chance of finding noninfringement as the number of cases per year increases. The magnitude of the effect is substantial, amounting to about an eight percentage point increase in the likelihood of finding noninfringement. Further, much of the effect seems to come at the low end of the experience cohort. Put another way, it is only the judges who very rarely see patent cases that tend to rule more often for the patentee on infringement. Even a modest volume of patent cases-corresponding to less than one final ruling every three years-is enough to drive a significantly higher rate of noninfringement findings. Once a judge has even a modest volume of patent cases, the effect levels off and further specialization does not appear to affect outcomes.

FIGURE 2

Chance of Noninfringement Finding by Experience Cohort

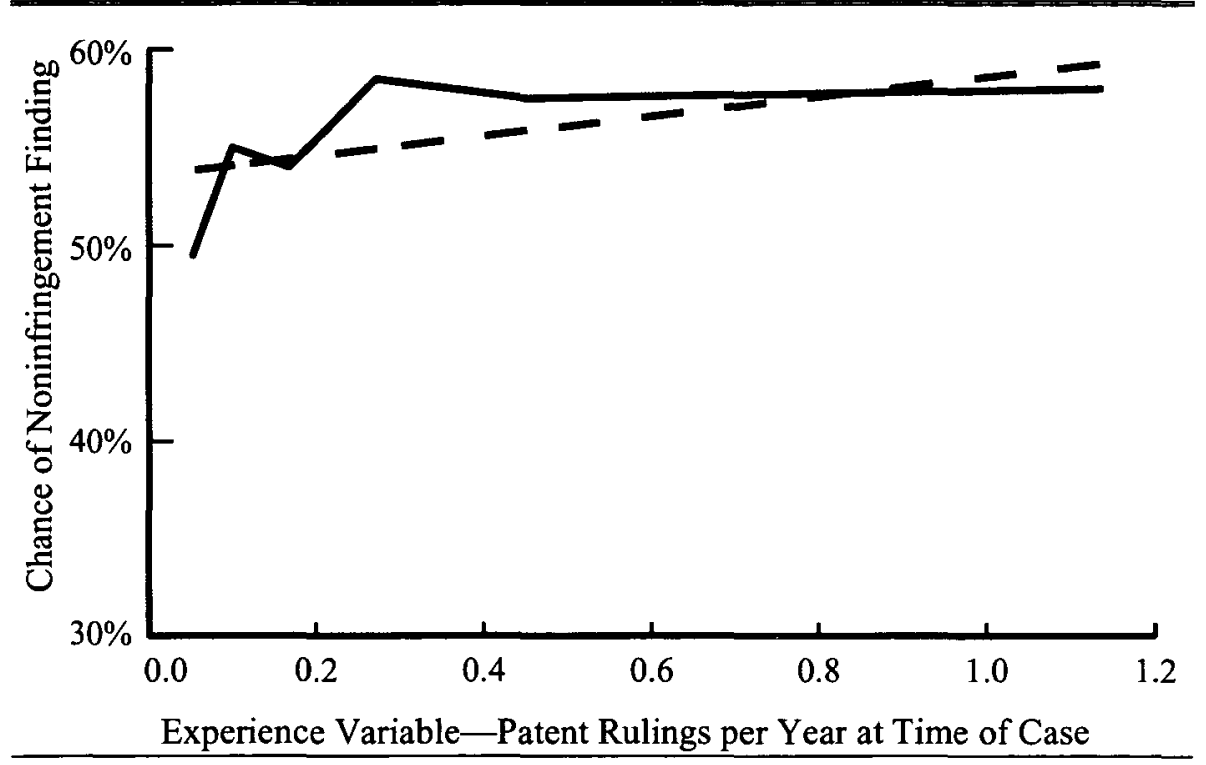

There is no corresponding increase in the chance of finding invalidity; while more experienced judges are slightly more likely to find patents invalid, that increase is not statistically significant. 
FIGURE 3

Chance of Invalidity Finding by Experience Cohort

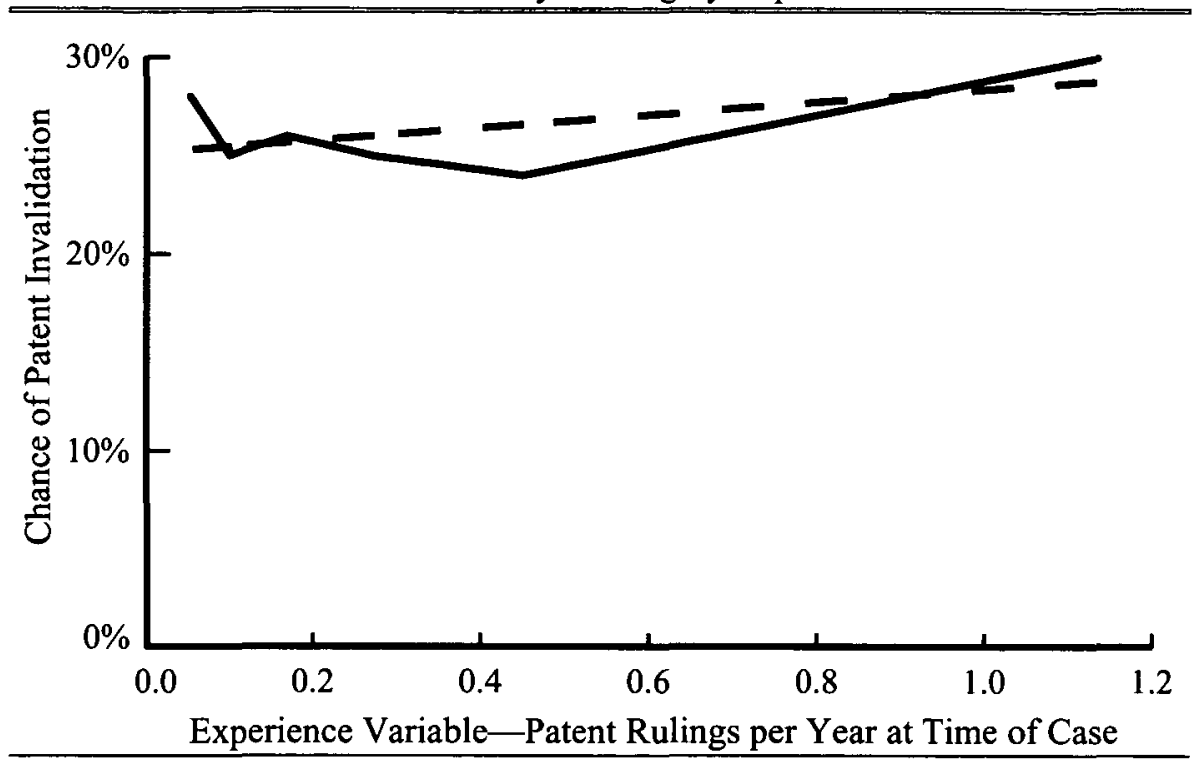

Each of the findings in the overall dataset is driven by the findings on infringement, not validity. Judges with more patent experience are more likely to find noninfringement, but not to find patents invalid. Judges in the District of Delaware and the District of New Jersey are more likely to find infringement, but not validity. Only the Northern District of California has a significant result on validity; judges there are more likely both to find patents invalid and to find them not infringed. But the Northern District of California finding may have an alternative explanation: the different mix of technology cases in the different districts.

\section{Technology-specific effects}

Both the District of Delaware and the District of New Jersey get a disproportionate share of pharmaceutical patent cases, and that may help explain our results in part. Pharmaceutical suits against generic drug companies are much less likely to turn on infringement issues for the simple reason that the generic has deliberately copied the active ingredient of the plaintiff's product in order to get quicker approval from the FDA. That doesn't mean there are never infringement disputes in pharmaceutical cases; patentees often sue on patents that 
cover inactive ingredients or dissolution profiles that the generic need not have copied. $^{69}$

To test that hypothesis, we categorized each litigated patent into one or more of nine different technology categories using the technology center classifications created by the U.S. Patent and Trademark Office (PTO). Those technology classifications are set out in Table 7. A patent can belong to more than one class, and many do. Further, many cases involve more than one patent, and we coded all technology centers involved in patents in the case. For both reasons, the numbers add to more than $100 \%{ }^{70}$

\section{TABLE 7}

Decisions by Patent Technology Center

\begin{tabular}{llc}
\hline Patent Technology Center & $\begin{array}{c}\text { Percentage of } \\
\text { Decisions }\end{array}$ \\
\hline 1600 & Biotechnology and Organic Chemistry & $8.8 \%$ \\
1700 & Chemical and Materials Engineering & $6.5 \%$ \\
2100 & $\begin{array}{l}\text { Computer Architecture, Software, and } \\
\text { Information Security }\end{array}$ & $15.9 \%$ \\
2400 & $\begin{array}{l}\text { Computer Networks, Multiplex Communica- } \\
\text { tion, Video Distribution, and Security }\end{array}$ & $19.2 \%$ \\
2600 & $\begin{array}{l}\text { Communications } \\
2800\end{array}$ & $\begin{array}{l}\text { Semiconductors, Electrical and Optical } \\
\text { Systems, and Components }\end{array}$ \\
2900 & $\begin{array}{l}\text { Designs } \\
3600\end{array}$ & $\begin{array}{l}\text { Transportation, Construction, Electronic } \\
\text { Commerce, Agriculture, National Security, } \\
\text { and License \& Review }\end{array}$ \\
3700 & $\begin{array}{l}\text { Mechanical Engineering, Manufacturing, and } \\
\text { Products }\end{array}$ & $11.5 \%$ \\
\hline
\end{tabular}

69. See C. Scott Hemphill \& Bhaven N. Sampat, When Do Generics Challenge Drug Patents?, 8 J. EMPIRICAL LEGAL STUD. 613, 619-21 (2011) (discussing patentee suits against generics); Lisa Larrimore Ouellette, Note, How Many Patents Does It Take to Make a Drug? Follow-On Pharmaceutical Patents and University Licensing, 17 Мiсн. TeleCOMM. \& TECH. L. REV. 299, 314 (2010) (noting that pharmaceutical patentees often obtain multiple patents covering a single drug).

70. We did not simply use the technology center that actually examined the patent. Rather, we studied each patent to determine the various technologies it claimed and assigned those technologies to the closest technology centers. 
As we suspected, some districts are much more likely to hear certain types of technology cases than others. Biotechnology cases, for instance, represent $8.8 \%$ of all patent lawsuits in our dataset, while computer hardware and software excluding Internet and telecommunications represent $15.9 \%$ of the lawsuits we studied. But in the District of Delaware, $35.0 \%$ of all lawsuits are biotechnology cases, while only $8.0 \%$ are computer hardware and software cases. In the Northern District of California, by contrast, the numbers are reversed: $6.3 \%$ of lawsuits are biotechnology cases, while $34.2 \%$ are computer hardware and software cases. ${ }^{71}$ This difference is highly statistically significant. ${ }^{72}$

\section{FIGURE 4}

Percentage of Decisions by Patent Technology Center

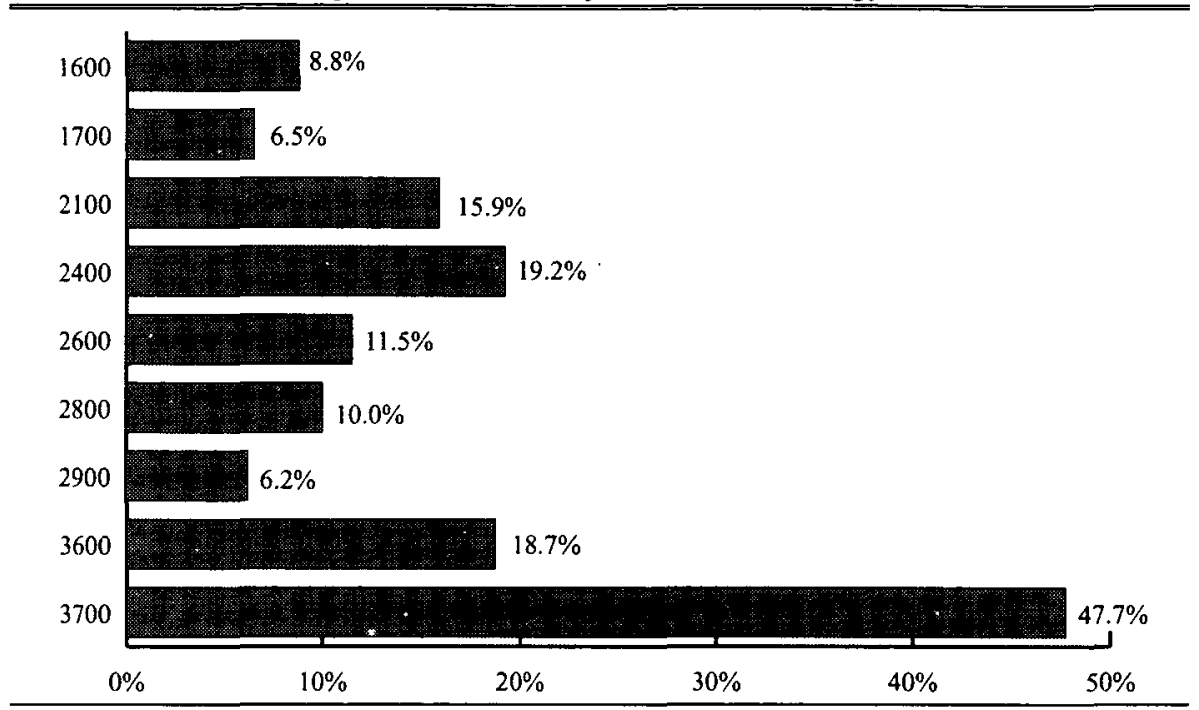

The technology differences matter because patentees are significantly more likely to win cases involving certain technologies (such as biotechnology and mechanical engineering) than others (such as computer hardware and software). When we reran our logistic regressions including technology center as a variable, the results were largely the same as those reported in Table 5 but with one significant exception: the Northern District of California was no longer less likely to rule for the patentee. The lower number of patentee wins in the Northern District of California appears to be an artifact of the large number of com-

71. Jeanne Fromer has suggested that we encourage technical specialization among courts by creating mechanisms that drive cases involving certain technologies to particular districts. Fromer, supra note 17, at 1444. But as our data suggest, we may already have such a system sorting biotechnology from software cases.

72. The full data for all districts and all technology classes are reported in Appendix A. 
puter technology cases filed there, coupled with the lower likelihood that a patentee will prevail in such a case. The District of Delaware, by contrast, remained more likely to rule for patentees even controlling for technology center. We report the results in Table 8.

TABLE 8

Logistic Regression Results with Technology Center Included ${ }^{73}$

\begin{tabular}{|lccccccc|}
\hline $\begin{array}{l}\text { Patentee Win } \\
\text { Experience }\end{array}$ & $\begin{array}{c}\text { Odds } \\
\text { Ratio }\end{array}$ & $\begin{array}{c}\text { Robust } \\
\text { Std. Err. }\end{array}$ & Z-Score & P-Value & \multicolumn{2}{c}{$\begin{array}{c}95 \% \text { Confidence } \\
\text { Interval }\end{array}$} \\
$\begin{array}{l}\text { Variable } \\
\text { Multipatent }\end{array}$ & 0.644 & 0.122 & -2.32 & $0.020^{*}$ & 0.444 & 0.934 \\
Case & 1.590 & 0.351 & 2.10 & $0.036^{*}$ & 1.031 & 2.450 \\
\hline $\begin{array}{l}\text { District } \\
\text { E.D. Tex. }\end{array}$ & 1.231 & 0.600 & 0.43 & 0.670 & 0.473 & 3.202 \\
\hline C.D. Cal. & 0.817 & 0.224 & 0.73 & 0.462 & 0.477 & 1.400 \\
\hline N.D. Cal. & 0.643 & 0.258 & -1.10 & 0.270 & 0.293 & 1.410 \\
\hline D. Del. & 1.967 & 0.743 & 1.79 & 0.073 & 0.938 & 4.124 \\
\hline N.D. Ill. & 0.985 & 0.360 & -0.04 & 0.967 & 0.481 & 2.018 \\
\hline S.D.N.Y. & 1.299 & 0.426 & 0.80 & 0.426 & 0.683 & 2.471 \\
\hline D.N.J. & 1.692 & 0.579 & 1.54 & 0.124 & 0.865 & 3.309 \\
\hline D. Mass. & 1.396 & 0.478 & 0.97 & 0.330 & 0.714 & 2.732 \\
\hline S.D. Fla. & 0.868 & 0.467 & -0.26 & 0.793 & 0.303 & 2.490 \\
\hline D. Minn. & 1.250 & 0.771 & 0.36 & 0.718 & 0.373 & 4.190 \\
\hline PTO Classification & & & & & \\
\hline 1600 & 1.606 & 0.426 & 1.78 & 0.074 & 0.954 & 2.702 \\
\hline 1700 & 0.696 & 0.233 & -1.08 & 0.279 & 0.362 & 1.341 \\
\hline 2100 & 0.431 & 0.132 & -2.75 & $0.006 *$ & 0.237 & 0.785 \\
\hline 2400 & 0.578 & 0.482 & -0.66 & 0.511 & 0.113 & 2.963 \\
\hline 2600 & 1.197 & 0.346 & 0.62 & 0.535 & 0.679 & 2.110 \\
\hline 2800 & 1.495 & 0.411 & 1.47 & 0.143 & 0.873 & 2.561 \\
\hline 2900 & 1.098 & 0.384 & 0.27 & 0.788 & 0.554 & 2.178 \\
\hline 3600 & 1.309 & 0.279 & 1.26 & 0.207 & 0.862 & 1.989 \\
\hline 3700 & 1.356 & 0.252 & 1.64 & 0.101 & 0.942 & 1.952 \\
\hline
\end{tabular}

73. The number of observations is slightly smaller than in previous Tables because we did not have reliable technology information for some cases. 


\begin{tabular}{|c|c|c|c|c|c|c|}
\hline \multicolumn{7}{|l|}{ Year } \\
\hline 2002 & 0.696 & 0.318 & -0.79 & 0.428 & 0.284 & 1.706 \\
\hline 2003 & 0.862 & 0.372 & -0.35 & 0.730 & 0.370 & 2.006 \\
\hline 2004 & 0.645 & 0.284 & -1.00 & 0.318 & 0.272 & 1.527 \\
\hline 2005 & 0.561 & 0.241 & -1.35 & 0.179 & 0.242 & 1.302 \\
\hline 2006 & 0.951 & 0.397 & -0.12 & 0.905 & 0.420 & 2.153 \\
\hline 2007 & 0.888 & 0.367 & -0.29 & 0.773 & 0.395 & 1.994 \\
\hline 2008 & 0.594 & 0.261 & -1.18 & 0.237 & 0.251 & 1.407 \\
\hline 2009 & 0.815 & 0.342 & -0.49 & 0.625 & 0.358 & 1.854 \\
\hline 2010 & 0.659 & 0.282 & -0.98 & 0.329 & 0.285 & 1.524 \\
\hline Constant & 0.300 & 0.122 & -2.96 & $0.003^{*}$ & 0.135 & 0.666 \\
\hline \\
\hline \multicolumn{7}{|c|}{$\begin{array}{l}\text { Significant at } 95 \% \text { level } \\
\text { Number of observations }=1092\end{array}$} \\
\hline \multicolumn{7}{|c|}{ Wald Chi-squared $(21)=48.59$} \\
\hline \multicolumn{7}{|c|}{ Pearson's Chi-squared $=0.0095$} \\
\hline \multicolumn{7}{|c|}{ Pseudo R-squared $=0.0559$} \\
\hline \multicolumn{7}{|c|}{ Log pseudo likelihood $=-528.2367$} \\
\hline
\end{tabular}

Biotechnology and pharmaceutical patentees are more likely to win ( $p=$ $0.074)$, while computer hardware and software patentees are significantly less likely to win. But the effect of judicial experience remains $(p=0.02)$. Notably, once we control for areas of technology, filing suit on multiple patents also is significantly correlated with the patentee winning. ${ }^{74}$

\section{The effect is driven by experience, not individual judges}

We have clearly identified a patent experience effect. But our data so far cannot tell us whether that effect results from the behavior of individual judges or whether it is more general. To test that, we experimented with adding judgespecific fixed effects. But because we have so many judges in the dataset (508), and so many of them decide only a few cases, adding fixed effects for every judge rendered the model unstable. As a result, we ended up including individual judge dummies for every judge with fifteen or more decisions to see whether particular judges influenced the result. ${ }^{75}$ We present the results in Table 9.

74. Multipatent cases were correlated with patentee win in each of our prior specifications, but only at the $90 \%$ confidence level.

75. Doing so necessitated dropping the district variables, which are collinear with individual judges. We also dropped the year variables, which we generally found not to be significant in prior models, to preserve sufficient degrees of freedom. 
None of the individual judges with significant numbers of cases was significantly more or less likely to rule for patentees. The findings of significance for both the biotechnology and software technology centers and the effect of judicial patent experience remained robust.

\section{TABLE 9}

Logistic Regression Results with Judge Fixed Effects

\begin{tabular}{|c|c|c|c|c|c|c|}
\hline $\begin{array}{l}\text { Patentee } \\
\text { Win }\end{array}$ & $\begin{array}{l}\text { Odds } \\
\text { Ratio }\end{array}$ & $\begin{array}{l}\text { Robust } \\
\text { Std. Err. }\end{array}$ & $\begin{array}{c}\text { Z- } \\
\text { Score }\end{array}$ & $\begin{array}{c}\text { P- } \\
\text { Value }\end{array}$ & \multicolumn{2}{|c|}{$\begin{array}{c}95 \% \text { Confidence } \\
\text { Interval }\end{array}$} \\
\hline $\begin{array}{l}\text { Experience } \\
\text { Variable }\end{array}$ & 0.586 & 0.147 & -2.13 & $0.033^{*}$ & 0.359 & 0.957 \\
\hline \multicolumn{7}{|c|}{ PTO Classification } \\
\hline 1600 & 1.803 & 0.490 & 2.17 & $0.030^{*}$ & 1.059 & 3.070 \\
\hline 1700 & 0.811 & 0.280 & -0.61 & 0.544 & 0.413 & 1.594 \\
\hline 2100 & 0.446 & 0.135 & -2.68 & $0.007^{*}$ & 0.247 & 0.805 \\
\hline 2400 & 0.561 & 0.452 & -0.72 & 0.473 & 0.116 & 2.720 \\
\hline 2600 & 1.192 & 0.337 & 0.62 & 0.534 & 0.685 & 2.075 \\
\hline 2800 & 1.341 & 0.368 & 1.07 & 0.285 & 0.783 & 2.297 \\
\hline 2900 & 0.980 & 0.325 & -0.06 & 0.953 & 0.512 & 1.879 \\
\hline 3600 & 1.228 & 0.259 & 0.98 & 0.329 & 0.813 & 1.856 \\
\hline 3700 & 1.385 & 0.245 & 1.84 & 0.066 & 0.979 & 1.960 \\
\hline Judge & $\begin{array}{l}\because \\
\vdots\end{array}$ & $\begin{array}{lll}3 & 0 \\
3 & 5 \\
\end{array}$ & $\cdots \cdots$ & 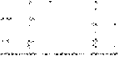 & $\therefore$ & $E$ \\
\hline \multicolumn{7}{|l|}{$A$} \\
\hline$B$ & 1.212 & 1063 & 0.22 & 0.827 & 0.217 & 6.757 \\
\hline$C$ & 3.398 & 2.273 & 1.83 & 0.068 & 0.916 & 12.608 \\
\hline $\begin{array}{l}D \\
E\end{array}$ & 1.083 & 0.939 & 0.09 & 0.927 & 0.198 & 5.923 \\
\hline$F$ & 1.503 & 1.600 & 0.38 & 0.702 & 0.187 & 12.110 \\
\hline$G$ & 2.476 & 1.502 & 1.49 & 0.135 & 0.754 & 8.129 \\
\hline \multicolumn{7}{|l|}{$H$} \\
\hline$I$ & 0.932 & 1.092 & -0.06 & 0.952 & 0.094 & 9.256 \\
\hline$J$ & 1.552 & 1.028 & 0.66 & 0.507 & 0.424 & 5.685 \\
\hline \multicolumn{7}{|l|}{$K$} \\
\hline$L$ & 1.720 & 1.551 & 0.60 & 0.548 & 0.293 & 10.077 \\
\hline$M$ & 2.552 & 1.454 & 1.64 & 0.100 & 0.835 & 7.796 \\
\hline \multicolumn{7}{|l|}{$N$} \\
\hline$O$ & 4.550 & 3.677 & 1.87 & 0.061 & 0.933 & 22.173 \\
\hline
\end{tabular}




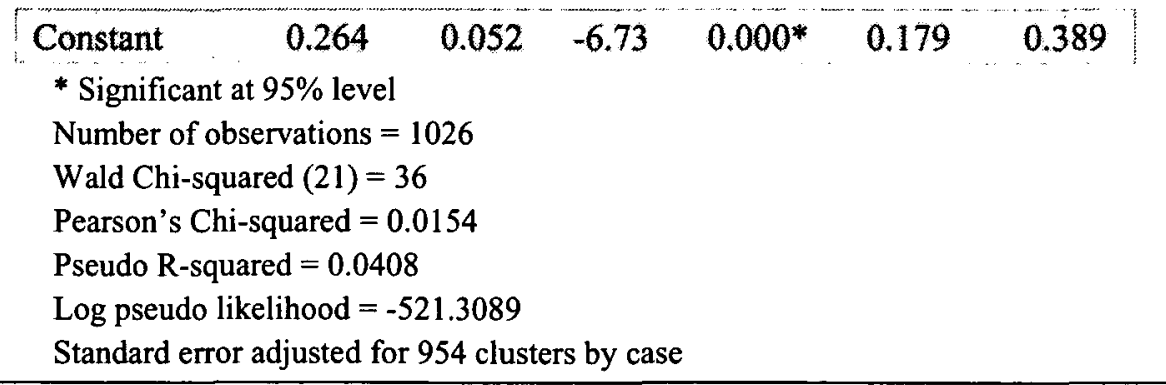

\section{IMPLICATIONS}

\section{A. Familiarity Breeds Contempt-Sometimes}

In some respects our findings confirm received wisdom. Patentees are well advised to bring suit on multiple patents if possible to increase the likelihood that at least one of those patents is found infringed. And, as expected, the benefit to patentees comes in findings of infringement, not validity; multiple bites at the apple give patentees better chances for at least one positive outcome. That has significant implications for portfolio theory; building a fence with many patents seems to be an effective strategy, which may help explain both why firms invest in it and why companies with the largest portfolios rarely have to resort to litigation to enforce them. ${ }^{76}$

It is also not surprising that patentees do better in certain plaintiff-friendly forums, such as the District of Delaware. The results of our technology center study might also have been expected. Most of the complaints about the patent system come from the computer industries, not from the biotechnology industries. Previous work shows that software patents are more likely to be declared invalid, ${ }^{77}$ as are patents wielded by nonpracticing entities, ${ }^{78}$ suggesting that sorting by industry is likely. And various scholars have suggested that the patent system works better in the life sciences industries than the computer indus-

76. See Mark A. Lemley \& A. Douglas Melamed, Missing the Forest for the Trolls, 113 Colum. L. Rev. 1001, 1015 (2013); Gideon Parchomovsky \& R. Polk Wagner, Patent Portfolios, 154 U. PA. L. REv. 1, 2, 7-8 (2005).

77. Shawn P. Miller, What's the Connection Between Repeat Litigation and Patent Quality? A (Partial) Defense of the Most Litigated Patents, 16 StAN. TeCH. L. ReV. 313, 334, 336 (2013); Shawn P. Miller, Where's the Innovation: An Analysis of the Quantity and Qualities of Anticipated and Obvious Patents, 18 VA. J.L. \& TECH. 1, 2, 49-50 (2013).

78. Allison et al., supra note 66, at 677. 
tries. ${ }^{79}$ Some of our district-specific results can accordingly be explained as a natural form of technology sorting by district. ${ }^{80}$

Our most significant result may be more surprising. We find that judges with more patent experience are less likely to rule for patentees on infringement, though not on validity. Familiarity, it seems, breeds contempt--not necessarily of patents, but of the breadth patentees sometimes claim for their legal rights.

Our data cannot tell us why more experienced patent judges are more likely to reject infringement claims. We do know that it is not a judge-specific or district-specific effect, that it seems to happen fairly quickly, and that it seems to be driven by the number of patent cases a particular judge has handled, not how long the judge has been on the bench. One possibility is simply greater confidence - that inexperienced patent judges are less likely to rule on summary judgment at all, or less likely to narrow the putative scope of a patentee's claims. But the data do not suggest any change in a judge's willingness to second-guess the PTO, which would have shown up as a change in the willingness to hold patents invalid. And both patentees and accused infringers move for summary judgment on infringement in roughly equal proportions, because infringement is driven by claim construction. So the change in judicial attitudes seems likely to be related to the substantive merits of patent claims, not to judges' greater willingness to address them head-on.

Perhaps judges who see a large number of patent cases are more likely to conclude that patentees overclaim the scope of their rights. There is certainly evidence to suggest that patent trolls-plaintiffs who make no products but sue those who do-tend to allege that their patents are extremely broad, covering entire industries. ${ }^{81}$ And the imprecision of claim language in many areas means that parties are likely to vary widely in what they think a patent claim covers. ${ }^{82}$ So one possibility is that once a judge has seen several patentees claiming to have invented an entire industry, she becomes more skeptical of patentee assertions that their patents are truly broad. ${ }^{83}$ This possibility finds some support in

79. See, e.g., James Bessen \& Michael J. Meurer, Patent Failure: How Judges, BUREAUCRATS, AND LAWYERS PUT INNOVATORS AT RISK 16 (2008).

80 . On the merits of resolving forum shopping by allowing "patent cases by technology" to naturally sort into different districts based on clusters of innovation, see Fromer, supra note 17 , at 1444 .

81. Allison et al., supra note 66, at 707; Mark A. Lemley, Software Patents and the Return of Functional Claiming, 2013 WIS. L. REV. 905, 907.

82. See BESSEN \& MEURER, supra note 79, at 8-9.

83. Judge Posner, for instance, has heard a number of patent cases and has recently expressed skepticism about the patent system as a whole. Richard A. Posner, Do Patent and Copyright Law Restrict Competition and Creativity Excessively?, BECKER-POSNER BLOG (Sept. 30, 2012), http://www.becker-posner-blog.com/2012/09/do-patent-and-copyright-lawrestrict-competition-and-creativity-excessively-posner.html. 
other work suggesting that patent trolls fare less well in court than others. ${ }^{84}$ Judges may also be finding noninfringement rather than invalidity because doing so is easier than ruling for the patentee (which often requires a trial) and somewhat more likely to survive Federal Circuit scrutiny than invalidating patents. ${ }^{85}$ We emphasize that we cannot prove either hypothesis with the data we have, but both seem plausible.

\section{B. The Promise and Peril of Judicial Specialization}

The fact that district court judges grow more likely to find against patentees as their experience with patent cases grows is a provocative finding that prompts a number of additional questions and paths for future work.

First, what is a "good" or "better" outcome for patent cases, and how is it measured? If you are an alleged infringer or concerned about overclaiming and patent threats, our results will seem logical and comforting. If you are a patentee seeking to assert, they will seem less so. If judges do grow more skeptical of patentee infringement claims as they see more overbroad claims, this has some interesting implications for patent reform. A number of proposals for judicial specialization center on the idea that a judge with more patent experience will make better decisions in patent cases. That seems reasonable to us, but it is worth noting that based on the evidence before us, "better" decisions tend to be decisions that favor accused infringers, not patentees, at least on the question of infringement. Specialization may be good, but whether you think it is good may well depend on the side of the fence on which you sit. And if it is right that more-specialized judges make better decisions, our evidence suggests that patentees are overclaiming the scope of their patents.

Our finding in turn means that seemingly good-government reform proposals like the PPP or calls for specialized district courts may have an unintended political valence. Our finding raises questions about how to measure whether reforms are working. The PPP's implementing legislation requires re-

84. E.g., Allison et al., supra note 66, at 677. But cf. Shawn P. Miller, Patent "Trolls": Rent-Seeking Parasites or Innovation-Facilitating Middlemen? (Apr. 2010) (unpublished manuscript), available at http://papers.ssm.com/sol3/papers.cfm?abstract_id=1885538 (measuring cases differently, focusing only on validity, and finding that trolls do not fare worse than others).

There is not yet a comprehensive database identifying patent trolls, but we hope in future work to test whether exposure to prior troll cases is more likely to lead judges to find noninfringement.

85. See, e.g., Roger Allan Ford, Patent Invalidity Versus Noninfringement, 99 CORNell L. REV. 71, 75-76 (2013) (opining that courts are too quick to rule on noninfringement rather than invalidity). Whether or not the Federal Circuit has a pro-patent "bias," previous empirical research has found that district judges are more likely to cite Federal Circuit precedent when ruling for the patentee than when ruling against it. David $\mathrm{R}$. Pekarek Krohn \& Emerson H. Tiller, Federal Circuit Patent Precedent: An Empirical Study of Institutional Authority and Intellectual Property Ideology, 2012 WIS. L. REV. 1177, 1177. 
porting by courts, but only some of the requirements can help address the-to be fair, perhaps ineffable - question of decision "quality," and those are limited to reviewing any general increase in expertise levels ${ }^{86}$ and Federal Circuit reversal rates, described as "efficiency." esting questions about the original goal of strengthening patents through the creation of the specialized Federal Circuit and about other areas of patent reform. Whether the district courts' high reversal rates in the Federal Circuit relate to a relative lack of experience with the law or technology or instead represent an informed view that patents are too strongly asserted from the court with the deepest experience with the facts in the case is an open question. But it is possible that the twin goals of increasing specialization and strengthening patents that jointly motivated the creation of the Federal Circuit are in some tension with each other. ${ }^{88}$

Second, how does one measure expertise? This is a longstanding question in the broader literature ${ }^{89}$ and is perhaps important here. Some have used technical education or work experience as a proxy. ${ }^{90}$ We considered including this, but we found the available information far too limited to create a useful measure; where judges' undergraduate and graduate backgrounds were available in publicly accessible sources, they often raised more questions than they answered. One person's bachelor of arts may be in physics, another in English. What technical training or knowledge accrued with that degree, and whether it has been maintained, is either unknowable without more detailed information or lost in the mists of time. The judge with a master's in English who has spent ensuing years becoming an autodidact in neuroscience-or simply being exposed to cutting-edge science through hearing evidence in a wide variety of civil and criminal cases-is hidden from view. Whether the judge's technical training is relevant to the case at issue depends heavily on the case. And so on. We think that judging experience with patent cases is the most direct measure. It also allows judges across the bench to be compared, apples to apples. ${ }^{91}$ Just the same, with better information, and perhaps a more qualitative methodology

86. 28 U.S.C. $\S 137$ note (2012) (Pilot Program in Certain District Courts).

87. Id.

88. Cases today are assigned randomly to judges whether they want patent cases or not. It is possible that judges who opt into the PPP will have different (and perhaps more favorable) views of the patent system than judges generally.

89. See Stuart Minor Benjamin \& Arti K. Rai, Who's Afraid of the APA? What the Patent System Can Learn from Administrative Law, 95 GEo. L.J. 269, 313-17 (2007); Daniel J. Meador, A Challenge to Judicial Architecture: Modifying the Regional Design of the U.S. Courts of Appeals, 56 U. CHI. L. REV. 603, 610-11 (1989).

90. E.g., Dunstan H. Barnes, Technically Speaking, Does It Matter? An Empirical Study Linking the Federal Circuit Judges' Technical Backgrounds to How They Analyze the Section 112 Enablement and Written Description Requirements, 88 CHI.-KENT L. REV. 971 (2013); Moore, supra note 46, at 245.

91. With the important caveat that, as discussed above, the technical subject matter and industry types involved vary widely across cases. 
such as surveys or interviews, knowing more about a judge's technical expertise might be able to help us better understand whether confidence with technical material is driving the learning effect we found.

Third, we looked at judges, not juries, for this study. It is also received wisdom that patentees want jury trials, and this wisdom is generally corroborated by consistent findings that juries are more likely than judges to find infringement and award higher damages. ${ }^{92}$ We made the rather surprising finding that judges in the "plaintiff-friendly" Eastern District of Texas show no difference in infringement outcomes compared to other courts in our study. Other work, however, shows that Eastern District of Texas juries may still favor patentees more than juries in other districts $\mathrm{do}^{93}$ and that there are more jury trials there than in most other districts. ${ }^{94}$ What that means for decisional quality and litigants is an interesting question that we cannot answer with this dataset alone. Similarly, our dataset does not capture the sometimes-subtle differences in procedure between district courts or the new patent-specific local rules that many courts are adopting.

\section{Future Work}

Our results and these remaining questions indicate some paths for further work. It is too early to see if judges who gain additional patent case experience through the PPP's channeling model will follow these overall results. Judges who self-select into hearing extra patent cases may have different views about patents and patentees than those who are randomly selected. An obvious follow-up would test whether the outcomes in PPP districts change over the ten years of the program and whether they differ substantially from the outcomes in districts not in the program. This would add some valence to the measures Congress has required courts to track and provide further important information about whether increased experience leads judges to reach different outcomes over time.

While we think experience with actual cases is the most direct measure of experience, data on the technical expertise of judges and whether such expertise affects outcomes would also add to our understanding of how cases are decided. Knowing whether any technical or patent litigation background-which may increase overall confidence with technical cases-matters, as well as whether case-specific technical expertise matters, would offer litigants more information and could indicate further paths for reform.

92. See PwC, supra note 32, at 5.

93. Lemley et al., supra note 53, at 178-84.

94. Lemley, supra note 65 , at 12 (finding that $8 \%$ of patent cases in the Eastern District of Texas make it to trial, more than in any other district except the District of Delaware). 
Finally, as noted, our results are necessarily limited in that they do not take into account differences in local rules and other specifics local to trial courts. More broadly, as the literature demonstrates, isolating the effects of specialist experience or expertise is an exceedingly complex task. Further theoretical modeling and empirical work would be helpful in better understanding the overall picture and the likely effects of reforms that target different aspects of litigation.

\section{CONCLUSION}

As judges gain experience with patent cases, they are less likely to rule for patentees on infringement. Our finding is strong and highly significant, robust across districts, across time, and across areas of technology. This both challenges existing assumptions about forum shopping in patent cases and suggests that specialized patent trial courts may benefit accused infringers over patentees. It has potentially profound implications for patent law, where it might lead us to question the way we design patents, and for the broader project of judicial specialization, which may have unintended substantive consequences. 
APPENDIX A

Percentage of Cases in Each District by Technology Center

\begin{tabular}{|c|c|c|c|c|c|c|c|c|c|}
\hline District & $\begin{array}{l}\text { PTO } \\
1600 \\
\end{array}$ & $\begin{array}{l}\text { PTO } \\
1700 \\
\end{array}$ & $\begin{array}{l}\text { PTO } \\
2100 \\
\end{array}$ & $\begin{array}{l}\text { PTO } \\
2400 \\
\end{array}$ & $\begin{array}{l}\text { PTO } \\
2600 \\
\end{array}$ & $\begin{array}{l}\text { PTO } \\
2800 \\
\end{array}$ & $\begin{array}{l}\text { PTO } \\
2900 \\
\end{array}$ & $\begin{array}{l}\text { PTO } \\
3600 \\
\end{array}$ & $\begin{array}{l}\text { PTO } \\
3700 \\
\end{array}$ \\
\hline D. Ariz. & $14 \%$ & $0 \%$ & $29 \%$ & $0 \%$ & $0 \%$ & $0 \%$ & $0 \%$ & $14 \%$ & $57 \%$ \\
\hline W.D. Ark. & $0 \%$ & $0 \%$ & $0 \%$ & $0 \%$ & $0 \%$ & $0 \%$ & $100 \%$ & $0 \%$ & $0 \%$ \\
\hline C.D. Cal. & $4 \%$ & $3 \%$ & $12 \%$ & $3 \%$ & $10 \%$ & $19 \%$ & $9 \%$ & $17 \%$ & $52 \%$ \\
\hline E.D. Cal. & $0 \%$ & $10 \%$ & $10 \%$ & $0 \%$ & $0 \%$ & $0 \%$ & $0 \%$ & $60 \%$ & $30 \%$ \\
\hline N.D. Cal. & $6 \%$ & $3 \%$ & $34 \%$ & $1 \%$ & $16 \%$ & $19 \%$ & $1 \%$ & $8 \%$ & $37 \%$ \\
\hline S.D. Cal. & $8 \%$ & $4 \%$ & $29 \%$ & $13 \%$ & $17 \%$ & $0 \%$ & $25 \%$ & $17 \%$ & $42 \%$ \\
\hline D. Colo. & $0 \%$ & $0 \%$ & $0 \%$ & $0 \%$ & $0 \%$ & $0 \%$ & $0 \%$ & $13 \%$ & $88 \%$ \\
\hline D. Conn. & $11 \%$ & $0 \%$ & $22 \%$ & $0 \%$ & $0 \%$ & $11 \%$ & $0 \%$ & $11 \%$ & $56 \%$ \\
\hline D. Del. & $35 \%$ & $6 \%$ & $8 \%$ & $2 \%$ & $11 \%$ & $8 \%$ & $0 \%$ & $11 \%$ & $62 \%$ \\
\hline D.D.C. & $14 \%$ & $0 \%$ & $29 \%$ & $0 \%$ & $0 \%$ & $0 \%$ & $0 \%$ & $14 \%$ & $57 \%$ \\
\hline MD. Fla. & $0 \%$ & $0 \%$ & $0 \%$ & $6 \%$ & $24 \%$ & $6 \%$ & $6 \%$ & $24 \%$ & $24 \%$ \\
\hline N.D. Fla. & $0 \%$ & $0 \%$ & $0 \%$ & $0 \%$ & $0 \%$ & $0 \%$ & $0 \%$ & $0 \%$ & $100 \%$ \\
\hline S.D. Fla: & $3 \%$ & $10 \%$ & $21 \%$ & $10 \%$ & $3 \%$ & $0 \%$ & $10 \%$ & $31 \%$ & $31 \%$ \\
\hline M.D. Ga. & $0 \%$ & $0 \%$ & $100 \%$ & $0 \%$ & $100 \%$ & $0 \%$ & $0 \%$ & $0 \%$ & $0 \%$ \\
\hline N.D.Ga. & $0 \%$ & $5 \%$ & $20 \%$ & $0 \%$ & $5 \%$ & $0 \%$ & $0 \%$ & $30 \%$ & $60 \%$ \\
\hline D. Idaho & $0 \%$ & $0 \%$ & $0 \%$ & $0 \%$ & $0 \%$ & $0 \%$ & $0 \%$ & $33 \%$ & $67 \%$ \\
\hline C.D. III. & $0 \%$ & $33 \%$ & $0 \%$ & $0 \%$ & $33 \%$ & $0 \%$ & $67 \%$ & $0 \%$ & $33 \%$ \\
\hline N.D. Ill. & $8 \%$ & $7 \%$ & $15 \%$ & $2 \%$ & $11 \%$ & $10 \%$ & $5 \%$ & $18 \%$ & $52 \%$ \\
\hline S.D. III & $0 \%$ & $0 \%$ & $0 \%$ & $0 \%$ & $100 \%$ & $0 \%$ & $0 \%$ & $0 \%$ & $0 \%$ \\
\hline N.D. Ind. & $0 \%$ & $0 \%$ & $0 \%$ & $0 \%$ & $0 \%$ & $0 \%$ & $0 \%$ & $33 \%$ & $67 \%$ \\
\hline S.D. Ind. & $38 \%$ & $0 \%$ & $0 \%$ & $0 \%$ & $0 \%$ & $13 \%$ & $13 \%$ & $50 \%$ & $50 \%$ \\
\hline W.D. Ky. & $0 \%$ & $0 \%$ & $0 \%$ & $100 \%$ & $0 \%$ & $0 \%$ & $0 \%$ & $0 \%$ & $0 \%$ \\
\hline N.D. lowa & $0 \%$ & $0 \%$ & $0 \%$ & $0 \%$ & $0 \%$ & $0 \%$ & $0 \%$ & $0 \%$ & $100 \%$ \\
\hline S.D. Iowa & $0 \%$ & $100 \%$ & $0 \%$ & $0 \%$ & $0 \%$ & $0 \%$ & $0 \%$ & $0 \%$ & $0 \%$ \\
\hline D. Kan. & $0 \%$ & $0 \%$ & $0 \%$ & $0 \%$ & $20 \%$ & $0 \%$ & $0 \%$ & $40 \%$ & $40 \%$ \\
\hline E.D. Ky. & $0 \%$ & $33 \%$ & $0 \%$ & $0 \%$ & $33 \%$ & $0 \%$ & $0 \%$ & $33 \%$ & $33 \%$ \\
\hline E.D. La. & $0 \%$ & $0 \%$ & $0 \%$ & $0 \%$ & $100 \%$ & $0 \%$ & $0 \%$ & $0 \%$ & $0 \%$ \\
\hline W.D. La. & $0 \%$ & $0 \%$ & $0 \%$ & $0 \%$ & $0 \%$ & $0 \%$ & $0 \%$ & $50 \%$ & $50 \%$ \\
\hline D. Me. & $0 \%$ & $100 \%$ & $0 \%$ & $0 \%$ & $0 \%$ & $0 \%$ & $0 \%$ & $0 \%$ & $100 \%$ \\
\hline D. Md. & $0 \%$ & $0 \%$ & $14 \%$ & $0 \%$ & $29 \%$ & $0 \%$ & $0 \%$ & $43 \%$ & $43 \%$ \\
\hline D. Mass. & $6 \%$ & $10 \%$ & $8 \%$ & $0 \%$ & $12 \%$ & $10 \%$ & $0 \%$ & $6 \%$ & $59 \%$ \\
\hline E.D. Mich. & $3 \%$ & $13 \%$ & $6 \%$ & $0 \%$ & $13 \%$ & $9 \%$ & $0 \%$ & $28 \%$ & $44 \%$ \\
\hline W.D. Mich. & $0 \%$ & $0 \%$ & $0 \%$ & $0 \%$ & $0 \%$ & $0 \%$ & $0 \%$ & $50 \%$ & $90 \%$ \\
\hline D. Minn. & $7 \%$ & $0 \%$ & $21 \%$ & $0 \%$ & $7 \%$ & $7 \%$ & $14 \%$ & $14 \%$ & $57 \%$ \\
\hline W.D. Mo. & $0 \%$ & $20 \%$ & $40 \%$ & $0 \%$ & $20 \%$ & $0 \%$ & $0 \%$ & $20 \%$ & $40 \%$ \\
\hline E.D. Mo. & $0 \%$ & $0 \%$ & $0 \%$ & $0 \%$ & $0 \%$ & $0 \%$ & $0 \%$ & $0 \%$ & $100 \%$ \\
\hline
\end{tabular}




\begin{tabular}{|c|c|c|c|c|c|c|c|c|c|}
\hline D. Nev. & $0 \%$ & $0 \%$ & $23 \%$ & $8 \%$ & $15 \%$ & $15 \%$ & $8 \%$ & $31 \%$ & $62 \%$ \\
\hline D. Neb. & $0 \%$ & $0 \%$ & $0 \%$ & $0 \%$ & $0 \%$ & $0 \%$ & $0 \%$ & $67 \%$ & $33 \%$ \\
\hline D.N.H. & $0 \%$ & $0 \%$ & $11 \%$ & $0 \%$ & $11 \%$ & $0 \%$ & $11 \%$ & $33 \%$ & $33 \%$ \\
\hline D.N.J. & $29 \%$ & $11 \%$ & $7 \%$ & $0 \%$ & $9 \%$ & $5 \%$ & $5 \%$ & $9 \%$ & 10 \\
\hline D.N.M. & $0 \%$ & $0 \%$ & $50 \%$ & $0 \%$ & $0 \%$ & $0 \%$ & $0 \%$ & $0 \%$ & $50 \%$ \\
\hline E.D.N.Y. & $0 \%$ & $0 \%$ & $13 \%$ & $0 \%$ & $20 \%$ & $0 \%$ & $13 \%$ & $13 \%$ & 53 \\
\hline N.D.N.Y. & $75 \%$ & $0 \%$ & $25 \%$ & $0 \%$ & $0 \%$ & $0 \%$ & $0 \%$ & $0 \%$ & \\
\hline S.D.N.Y. & $18 \%$ & $7 \%$ & $13 \%$ & $2 \%$ & $8 \%$ & $10 \%$ & $7 \%$ & $8 \%$ & \\
\hline W.D.N.Y. & $0 \%$ & $0 \%$ & $0 \%$ & $0 \%$ & $33 \%$ & $0 \%$ & $0 \%$ & $33 \%$ & $67^{\circ}$ \\
\hline E.D.N.C. & $0 \%$ & $50 \%$ & $0 \%$ & $0 \%$ & $0 \%$ & $0 \%$ & $0 \%$ & $0 \%$ & $50^{\circ}$ \\
\hline M.D.N.C. & $0 \%$ & $0 \%$ & $0 \%$ & $0 \%$ & $0 \%$ & $0 \%$ & $0 \%$ & $50 \%$ & $100 \%$ \\
\hline W.D.N.C. & $0 \%$ & $0 \%$ & $0 \%$ & $0 \%$ & $25 \%$ & $25 \%$ & $0 \%$ & $0 \%$ & 75 \\
\hline N.D. Ohio & $0 \%$ & $8 \%$ & $8 \%$ & $0 \%$ & $8 \%$ & $0 \%$ & $0 \%$ & $38 \%$ & 54 \\
\hline S.D. Ohio & $0 \%$ & $0 \%$ & $11 \%$ & $0 \%$ & $11 \%$ & $0 \%$ & $11 \%$ & $44 \%$ & \\
\hline D. Or. & $20 \%$ & $25 \%$ & $15 \%$ & $5 \%$ & $5 \%$ & $10 \%$ & $10 \%$ & $20 \%$ & $30^{\circ}$ \\
\hline N.D. Okla. & $0 \%$ & $0 \%$ & $0 \%$ & $0 \%$ & $0 \%$ & $0 \%$ & $0 \%$ & $100 \%$ & \\
\hline W.D. Okla & $0 \%$ & $20 \%$ & $0 \%$ & $0 \%$ & $0 \%$ & $0 \%$ & $0 \%$ & $40 \%$ & $40 \%$ \\
\hline E.D. Pa. & $8 \%$ & $0 \%$ & $8 \%$ & $0 \%$ & $8 \%$ & $8 \%$ & $8 \%$ & $25 \%$ & $42 \%$ \\
\hline M.D. Pa. & $0 \%$ & $0 \%$ & $0 \%$ & $0 \%$ & $0 \%$ & $50 \%$ & $0 \%$ & $50 \%$ & \\
\hline W.D. Pa. & $17 \%$ & $0 \%$ & $17 \%$ & $0 \%$ & $0 \%$ & $0 \%$ & $0 \%$ & $33 \%$ & $67 \%$ \\
\hline DRI & $0 \%$ & $50 \%$ & $0 \%$ & $0 \%$ & $0 \%$ & $50 \%$ & $0 \%$ & $0 \%$ & $50 \%$ \\
\hline D.S.C. & $18 \%$ & $36 \%$ & $0 \%$ & $0 \%$ & $9 \%$ & $9 \%$ & $0 \%$ & $36 \%$ & $45 \%$ \\
\hline E.D. Tenn, & $0 \%$ & $0 \%$ & $0 \%$ & $0 \%$ & $0 \%$ & $25 \%$ & $25 \%$ & $25 \%$ & $50 \%$ \\
\hline M.D. Tenn. & $0 \%$ & $0 \%$ & $0 \%$ & $0 \%$ & $0 \%$ & $25 \%$ & $0 \%$ & $0 \%$ & $75 \%$ \\
\hline W.D. Tenn. & $0 \%$ & $0 \%$ & $0 \%$ & $0 \%$ & $0 \%$ & $0 \%$ & $0 \%$ & $0 \%$ & $100 \%$ \\
\hline E.D. Tex. & $4 \%$ & $7 \%$ & $35 \%$ & $4 \%$ & $26 \%$ & $17 \%$ & $4 \%$ & $15 \%$ & $28 \%$ \\
\hline N.D Tex & $0 \%$ & $6 \%$ & $11 \%$ & $0 \%$ & $22 \%$ & $22 \%$ & $28 \%$ & $17 \%$ & $17 \%$ \\
\hline S.D. Tex. & $0 \%$ & $15 \%$ & $30 \%$ & $0 \%$ & $10 \%$ & $10 \%$ & $10 \%$ & $20 \%$ & $35 \%$ \\
\hline W.D. Tex. & $0 \%$ & $11 \%$ & $22 \%$ & $0 \%$ & $22 \%$ & $0 \%$ & $22 \%$ & $11 \%$ & $33 \%$ \\
\hline D. Utah & $0 \%$ & $0 \%$ & $10 \%$ & $0 \%$ & $0 \%$ & $0 \%$ & $50 \%$ & $30 \%$ & $70 \%$ \\
\hline D. Vt: & $0 \%$ & $0 \%$ & $50 \%$ & $0 \%$ & $0 \%$ & $50 \%$ & $0 \%$ & $0 \%$ & $0 \%$ \\
\hline E.D. Va. & $13 \%$ & $7 \%$ & $27 \%$ & $0 \%$ & $27 \%$ & $0 \%$ & $7 \%$ & $20 \%$ & $33 \%$ \\
\hline W.D. Wash. & $6 \%$ & $6 \%$ & $31 \%$ & $0 \%$ & $6 \%$ & $13 \%$ & $13 \%$ & $19 \%$ & $44 \%$ \\
\hline E.D. Wis. & $0 \%$ & $0 \%$ & $0 \%$ & $0 \%$ & $0 \%$ & $0 \%$ & $0 \%$ & $67 \%$ & $33 \%$ \\
\hline W.D. Wis. & $5 \%$ & $9 \%$ & $27 \%$ & $0 \%$ & $14 \%$ & $23 \%$ & $0 \%$ & $18 \%$ & $32 \%$ \\
\hline Nationwide & $9 \%$ & $7 \%$ & $16 \%$ & $2 \%$ & $12 \%$ & $10 \%$ & $6 \%$ & $19 \%$ & \\
\hline
\end{tabular}


